\title{
Do Financial Analysts Play a Complementary or Substitutive Role in the Corporate Information Environment? Evidence from Organised Labour
}

\author{
Steven Xianglong Chen* \\ Accounting and Finance Group \\ University of Liverpool Management School \\ Liverpool, L69 3BX, UK \\ s.x.chen@liverpool.ac.uk \\ (*corresponding author)
}

Edward Lee

Division of Accounting and Finance

Alliance Manchester Business School

The University of Manchester

Manchester, M15 6PB, UK

Edward.Lee@manchester.ac.uk

\section{Konstantinos Stathopoulos}

Division of Accounting and Finance

Alliance Manchester Business School

The University of Manchester

Manchester, M15 6PB, UK

K.Stathopoulos@manchester.ac.uk

Current version: January 2020

The authors gratefully acknowledge the valuable discussions and comments from Zhangfan Cao, Theodore Christensen, Mohamed Ghaly, Chen Hua, Simon Jonghwan Kim, James Ohlson, Neslihan Ozkan, Andrew Stark and Norman Strong. Steven Xianglong Chen is grateful for financial support from Alliance Manchester Business School and The University of Manchester during his doctoral research. 


\title{
Do Financial Analysts Play a Complementary or Substitutive Role in the Corporate Information Environment? Evidence from Organised Labour
}

\begin{abstract}
This paper explores the primary role of financial analysts in the context of unionised firms, where investors have greater information demand. Previous literature suggests that labour unions create substantial uncertainty in firms and undermine the information environment, while another strand of literature argues that analysts devote more effort to generating valuable information through original research in the case of heightened uncertainty or information asymmetry. To date, it is unclear whether financial analysts, as professional information intermediaries, are affected by organised labour. Using a large U.S. sample over the period of 1983-2015, we find that the labour unionisation rate is associated with lower forecast accuracy and higher forecast dispersion, suggesting that financial analysts predominantly play a "complementary role" rather than a "substitutive role" when firms are facing significant uncertainty in human capital. Overall, our study has important implications for managers, financial analysts and regulators, by highlighting the value and hence necessity of non-financial information disclosure specific to a key intangible asset of firms, i.e., their employees.
\end{abstract}

Keywords: financial analysts; information intermediary; earnings forecast; uncertainty; human capital management; labour unions 
“...the strike potentially cost shareholders $\$ 0.05$ to $\$ 0.07$ in earnings per share for the second quarter..."

- Verizon CFO (Reuters 2016)

\section{Introduction}

It is widely accepted that financial analysts play two important roles as key information intermediaries in the capital markets: (1) a complementary role ${ }^{1}$, facilitating the dissemination of publicly available information from firms to investors and (2) a substitutive role ${ }^{2}$, generating value-relevant information through their original and specialised research that would not otherwise be available to the markets, as a substitution for corporate disclosure (Lang and Lundholm 1996; Asquith et al. 2005; Beyer et al. 2010; Bradshaw et al. 2017). While financial analysts' contribution to the information environment as information intermediaries has been extensively discussed and recognised in the extant accounting and finance literature (Beyer et al. 2010; Bradshaw et al. 2017), whether and how financial analysts might be affected by organised labour remains an open question. In light of the increasingly important role of human capital in today's corporate environment, in this paper, we explore the behaviour of financial analysts in the context of organised labour.

Unlike other stakeholders, organised labour constitutes a powerful stakeholder that not only exists internally within the firm but also has a significant financial claim in the form of wages and pensions (Faleye et al. 2006; Campello et al. 2018). Prior union literature has mainly focused on the labour-management interplay and established that labour unions not only use their collective bargaining power to safeguard employees' interests but also exert influence over a wide range of corporate decisions (Klasa et al. 2009; Matsa 2010; Chyz et al. 2013; Chung et al. 2016; Bradley et al. 2017c; Huang et al. 2017; Hamm et al. 2018). In response, to mitigate labour risk and undermine union power, managers strategically obfuscate information to improve their bargaining position against the labour unions (Hilary 2006; Bova 2013; Chung et al. 2016). Thus, given the greater uncertainty in human capital and information asymmetry, investors and other market participants are likely to have an increased demand for information and consequently analyst services. While recent papers (Loh and Stulz 2018; Jennings 2019) attempt to study the

\footnotetext{
1 Some studies also term this role "information dissemination" (Kross et al. 1990; Bradshaw et al. 2017) or "information interpretation" (Chen et al. 2010; Livnat and Zhang 2012; Huang et al. 2018). For consistency, we use the term "complementary role" hereafter in this paper.

2 Some papers term this "information provision"(Lang and Lundholm 1996), the "informational role" (Bradshaw et al. 2017; Jennings 2019) or "information discovery" (Chen et al. 2010; Livnat and Zhang 2012; Huang et al. 2018). For consistency, we use the term "substitutive role" hereafter in this paper.
} 
role of financial analysts using more extreme settings, such as economic recessions or managerial misconduct lawsuits, we believe that focusing on organised labour, an internal stakeholder that directly participates in day-to-day business operations, is likely to help us tease out the primary role of financial analysts, with greater generalisability. Hence, in this paper, we specifically investigate how financial analysts perform when making forecasts for firms facing uncertainty in human capital.

Informed by the two roles financial analysts play in the capital markets, we develop two competing hypotheses regarding the direction of the unions' influence on analysts' earnings forecasts: (1) a "complementary role" and (2) a "substitutive role". On the one hand, if financial analysts primarily serve a "complementary role" by distributing and interpreting existing information disclosed by firms to investors, we would predict that both the direct and indirect impact of labour unions on the information environment would lead to lower forecast quality. Directly, labour unions can affect analyst forecasts by introducing substantial uncertainty into business operations and future earnings prospects (Clark 1984; Ruback and Zimmerman 1984; Connolly et al. 1986; Chen et al. 2011). To be specific, given the wage agenda, labour unions engage in collective-bargaining strategies to push for higher wages and better welfare for the employees, thereby causing significant uncertainty in labour costs, which constitute a major component of a firm's annual expenditure ${ }^{3}$. Consequently, union presence can have substantial implications for profit margins, and ultimately analysts' ability to predict future earnings, if financial analysts predominantly rely on readily available information in the public domain. On top of the uncertainty in labour costs, labour unions have the ability to unilaterally initiate largescale labour strikes, which can be extremely disruptive to firms' operations and detrimental to financial performance (Ashenfelter and Johnson 1969; Becker and Olson 1986; Myers and Saretto 2016). ${ }^{4}$ Therefore, firms facing strong unions are exposed to significantly higher strike risk. Thus, from the perspective of financial analysts acting as information disseminators, we postulate that financial analysts, ex ante, can neither predict an occurrence nor quantify the economic consequence of a strike when forecasting future earnings. Additionally, labour unions can cause uncertainties and inflexibilities in the implementation of corporate strategies, especially when those strategies are expected to have negative implications for the employees (Atanassov

\footnotetext{
${ }^{3}$ For instance, the total payroll and benefits in 2008 in the manufacturing sector, where labour unions are more prevalent and active, were $\$ 784$ billion, more than four times the total capital expenditure, at $\$ 166$ billion, in the same year (Hamm et al. 2018).

4 This is also supported by the anecdotal evidence. Following a high-profile strike involving more than 40,000 Verizon employees in 2016, the CFO of Verizon at the time estimated that "the strike potentially cost shareholders $\$ 0.05$ to \$0.07 in earnings per share" (Reuters 2016), while the Wall Street Journal (2016) reported that the sevenweek Verizon strike had cost the largest U.S. telecommunication provider $\$ 343$ million in revenue.
} 
and Kim 2009; Chen et al. 2011). While financial analysts closely follow corporate strategies, which are highly relevant to future economic prospects, it is unlikely that companies will voluntarily disclose the extent to which their own employees might or might not cooperate in the delivery of such corporate strategies. On top of the uncertainty labour unions bring to businesses, building on the argument that managers strategically preserve information asymmetry to obfuscate their financial position in the presence of labour unions (Liberty and Zimmerman 1986; Hilary 2006; Chung et al. 2016), financial analysts may also be indirectly affected by labour unions due to the deteriorated information environment in unionised firms. Taking these arguments together, consistent with financial analysts primarily engaging in a "complementary role", we hypothesise that analysts' earnings forecast quality will be lower for firms with a high degree of labour unionisation.

On the other hand, if financial analysts perceive themselves more as information providers and thus primarily play a "substitutive role", we would expect them to devote more resources to and exert more efforts towards generating more value-relevant information through original research in the context of unionised firms. In response to the increased uncertainty in human capital and deterioration in the information environment due to union presence, investors will have a greater demand for information, particularly from financial analysts, who are uniquely positioned to produce high-quality information for investors, regarding a firm's future economic prospects (Lang and Lundholm 1996; Jennings 2019). In fact, financial analysts are ideally suited to generate valuable information for investors. First of all, they have privileged access to information from multiple sources (Huang et al. 2018). When managerial disclosure is limited or less credible, financial analysts can still access valuable information from other channels, such as original research, and private interactions with senior management, rank-and-file employees, customers, and competitors (Soltes 2014; Huang et al. 2018). In addition to the information advantage, financial analysts have the skills and expertise to process and aggregate financial information from various sources to generate more informative analyst reports for investors (Healy and Palepu 2001; Bradshaw 2011; Huang et al. 2018). Thirdly, financial analysts possess industry-specific knowledge that is proven to be extremely valuable to investors, given that analysts typically follow firms within a particular sector and may also have gained industry insights through their professional experience (Bradley et al. 2017a; Jennings 2019). Empirically, the "substitutive role" of financial analysts has also been documented in the prior literature (Chen et al. 2010; Bradley et al. 2017a; Huang et al. 2018; Jennings 2019). Therefore, assuming financial analysts are primarily committed to generating first-hand information through individual research (substitutive role), given the greater information asymmetry and uncertainty in 
unionised firms, we would expect financial analysts to be more diligent in producing original and value-relevant information for firms facing collective bargaining, in order to meet the information demand from the investors. Hence, analysts' forecast quality is likely to be higher for unionised firms.

Hence, in this paper, we aim to disentangle the dual role of financial analysts by investigating the analysts' forecast quality in the presence of strong employee power. Using a large panel dataset over the period of 1983-2015, we find that the labour unionisation rate is associated with significantly lower forecast accuracy and higher forecast dispersion, suggesting that the "complementary role" of financial analysts dominates the "substitutive role". ${ }^{5}$ Further tests controlling for financial reporting quality confirm that there is an incremental union effect that cannot be fully explained by managerial obfuscation in unionised firms (Hilary 2006; Chung et al. 2016). Therefore, we interpret this incremental effect as evidence consistent with labour union representation incorporating inherent uncertainties that are difficult for financial analysts to capture precisely in their earnings forecasts.

Subsample analyses indicate that the union impact on analyst forecast properties is more pronounced for (1) firms headquartered in non-RTW (right-to-work) states, where unions enjoy greater bargaining power, and (2) firms operating in low-skilled industries, where unions play a more active role. Crucially, we find that the disclosure of labour-related expenses can effectively mitigate the union effect on analysts' earnings forecast quality, confirming that the financial analysts predominantly rely on publicly disclosed information, instead of generating such information through original research. This analysis also lends additional support to our "uncertainty channel”, whereby labour unions affect financial analysts' ability to forecast future earnings by creating substantial uncertainties in labour costs. Last but not least, we show that financial analysts are more likely to issue optimistic forecasts for unionised firms, consistent with financial analysts' strategic optimism in response to the higher uncertainty in human capital, and lower earnings predictability, for unionised firms.

\footnotetext{
${ }^{5}$ It should be noted that we are not at all suggesting that financial analysts are not generating new information for investors and the capital markets. In fact, the premise of our research is that financial analysts do perform both functions, which is supported in the prior literature. The conclusion we draw from the empirical analyses is that, on aggregate, the "complementary role" seems to dominate, meaning that financial analysts engage more in disseminating information that is publicly available than in generating original and valuable information. In other words, if financial analysts overwhelmingly perceived themselves as information providers, and were diligently conducting research on unionised firms, we would not have documented such a negative association between labour unionisation and forecast quality.
} 
Our study contributes to the literature in multiple ways. First of all, our study contributes to the ongoing debate on the primary role of financial analysts in the capital markets, against the backdrop of innovation in information technology and transformation of the information environment (Lang and Lundholm 1996; Altınkılıç et al. 2013; Loh and Stulz 2018; Schantl 2018; Huang et al. 2018; Jennings 2019). Different from Loh and Stulz (2018) and Jennings (2019), who examine the role of financial analysts under extreme circumstances (e.g., economic recessions and managerial lawsuits), we study analysts' performance in the context of strong power of employees, a common key stakeholder playing an increasingly important role in today's economy. By exploiting the uncertainty in human capital within unionised firms, our study suggests that financial analysts, on aggregate, predominantly engage in information dissemination over information discovery. Thus, our study provides additional insights into analysts' behaviour and performance in the context of strong employee power.

Secondly, our study extends the understanding of the influence of the employees as an internal stakeholder, and more specifically its role in capital markets. While previous studies have focused on unions' influence on firm decisions (Klasa et al. 2009; Matsa 2010; Chung et al. 2016; Chino 2016; Bradley et al. 2017c; Huang et al. 2017; Hamm et al. 2018), our results suggest employees' influence extends well beyond the firms to a group of sophisticated market participants, i.e., financial analysts, and can potentially affect the information environment of the capital markets. While previous studies argue that managers strategically preserve information asymmetry in order to improve their bargaining position against labour unions (Hilary 2006; Bova 2013; Chung et al. 2016), our study offers a more direct "uncertainty channel" by showing that the presence of union representation itself constitutes an inherent uncertainty that materially undermines financial analysts' ability to predict future earnings.

Last but not least, our study has important implications for financial analysts, managers and policymakers. Our paper echoes the chronic concern on the usefulness of financial report information and the call for more relevant disclosure of non-financial information to complement financial reporting regimes (Amir and Lev 1996; Aboody and Lev 1998; Francis and Schipper 1999; Lev 2018). Similarly to Amir and Lev (1996) and Dhaliwal et al. (2012), we highlight that human capital information, typically considered secondary to conventional financial statements, can be highly relevant to investors. Therefore, when making earnings forecasts, financial analysts should place more emphasis on non-financial information related to human capital, which is a valuable intangible asset of a firm (Amir et al. 2003). Our study also encourages managers to make more specific disclosures on their human capital to transparently 
communicate information about labour-management relations to their investors, thus signalling quality to the market. Given the growing importance of employees in today's knowledgeintensive economic environment, regulators and standard setters may also consider mandatory disclosure on human capital investment, to supplement the existing financial reporting systems and enhance the overall information environment of the capital markets (Amir and Lev 1996; Amir et al. 2003; Lev 2018). Overall, our study sheds light on the primary role of financial analysts by examining the interplay between financial analysts and a powerful internal stakeholder, the employees.

The remainder of the paper is organised as follows. Section 2 reviews the extant literature and develops our research hypotheses. Section 3 describes our sample and the empirical design we use in our analyses. Section 4 presents the main empirical results. Section 5 summarises the findings and contributions of this study.

\section{Related Literature and Hypothesis Development}

\subsection{Related Literature}

\subsubsection{Financial Analysts}

Financial analysts are key information intermediaries who bridge the informational gap between companies and investors in the capital markets (Bradshaw et al. 2017). Through their collection and research of value-relevant information, financial analysts make earnings forecasts and stock recommendations to investors, playing a central role in facilitating the information flows and efficient functioning of capital markets (Lang and Lundholm 1996; Healy and Palepu 2001; Beyer et al. 2010).

Much of the analyst literature focuses on the influence of financial analysts on capital markets. First and foremost, empirical evidence confirms that financial analysts, as information intermediaries, play an effective role in significantly reducing the information asymmetry between companies and investors (Beyer et al. 2010; Mansi et al. 2011; Bradshaw et al. 2017). In addition to facilitating the dissemination of value-relevant information that exists in the markets (complementary role), financial analysts, prior literature suggests, can also generate original and informative research, thus increasing the supply of useful information in the capital markets (substitutive role) (Huang et al. 2018; Jennings 2019). Specifically, prior studies suggest that analysts' level of experience and skills (Clement 1999; Hashim and Strong 2018) and pre-analyst industry expertise (Bradley et al. 2017a) are conducive to their generation of first-hand, valuable outputs 
that are provided to information users such as investors. Meanwhile, cultural diversity also enhances the quality of analysts' earnings forecasts, as Merkley et al. (2017a) find that a high level of cultural diversity amongst a group of sell-side analysts, typically within the same brokerage firm, significantly improves the accuracy and reduces the optimism bias and dispersion of the consensus forecasts.

In addition to improving the information environment, prior literature has shown that financial analysts perform an external governance role by carrying out strong monitoring of managerial behaviours (Yu 2008; Irani and Oesch 2013; Chen et al. 2015; Bradley et al. 2017b; Chen and Lin 2017; Chen et al. 2018). Specifically, previous studies present evidence that analyst coverage can improve financial reporting quality (Irani and Oesch 2013; Bradley et al. 2017b) and deter opportunistic managerial behaviours such as expropriation of shareholders' wealth (Chen et al. 2015), earnings management ( $\mathrm{Yu}$ 2008; Bradley et al. 2017b) and tax avoidance (Chen and Lin 2017; Chen et al. 2018). Recent studies suggest that financial analysts have a positive influence on corporate investment efficiency (Chen et al. 2017) and the quality of investment decisions (To et al. 2018).

Notwithstanding their contribution to the efficient functioning of capital markets, financial analysts do inevitably rely on the information environment at the same time, in order to fulfil their roles in the capital markets (Lang and Lundholm 1996; Healy and Palepu 2001; Hope 2003a). Amongst various sources of information, a crucial and essential type comes from financial reporting, predominantly financial statements and annual reports (Healy and Palepu 2001). While financial information certainly plays a central role in financial analysts' careers, Dhaliwal et al. (2012) find that the introduction of CSR reports improves financial analysts' forecast accuracy, suggesting that financial analysts also refer to non-financial information. Another main source of information that analysts pay active attention to is corporate disclosure. Such disclosure, though issued on a voluntary basis, is evidently informative to them and is associated with higher earnings forecast accuracy (Lang and Lundholm 1996; Healy and Palepu 2001; Hope 2003a; Hope 2003b).

Alongside information availability, the quality of the information itself is equally pivotal to financial analysts. One of the most important factors in information quality is the institutional environment within which the information is disseminated (Hope 2003a; Lang et al. 2003; Tan et al. 2011; Horton et al. 2013). For example, Lang et al. (2003) show that firms that are cross-listed on U.S. stock exchanges enjoy greater analyst coverage and higher forecast accuracy, attributable to the better information environment in the U.S. Similarly, using an international sample, Hope 
(2003a) finds that earnings forecasts are more accurate in countries with strong enforcement of accounting standards. In addition to regulation and enforcement, accounting standards can have a material impact on financial reporting quality, and consequently the precision of financial analysts' earnings forecasts. Previous studies document that forecast accuracy increases significantly following the adoption of International Financial Reporting Standards (IFRS), which significantly enhance the transparency and comparability of financial information (Tan et al. 2011; Horton et al. 2013; Petaibanlue et al. 2015). As well as institutional factors, auditors can have a direct impact on the usefulness of financial information. Behn et al. (2008) find that analysts' earnings forecasts are more accurate for firms audited by Big 5 auditors, suggesting that higher audit quality significantly improves the credibility and informativeness of financial statements. De Franco et al (2011) find that financial statement comparability also enhances analysts' earnings forecasts. Meanwhile, other studies suggest that the disclosure of accounting policies (Hope 2003b) and corporate governance (Bhat et al. 2006; Byard et al. 2006) is incrementally useful information, leading to more accurate earnings forecasts from analysts.

In addition to the reliance on the existing information environment, financial analysts, despite being professionally qualified experts, are likely to be affected by the inherent complexity and uncertainty of the underlying businesses (Barron and Stuerke 1998; Barron et al. 2002; Zhang 2006a; Mattei and Platikanova 2017; Amiram et al. 2018). When uncertainty about future earnings is high, analysts' earnings forecasts tend to be less accurate and more dispersed, albeit issued in a more timely manner (Zhang 2006a; Amiram et al. 2018). In other words, business complexity and uncertainty regarding future earnings are difficult for financial analysts to capture precisely in their earnings forecasts (Duru and Reeb 2002; Barron et al. 2002; Mattei and Platikanova 2017). Specifically, Barron et al. (2002) find that earnings forecasts tend to be less accurate and more dispersed for firms with high levels of intangible assets, while Duru and Reeb (2002) show that analysts issue less accurate and more optimistic earnings forecasts for firms with higher levels of international diversification. Recently, Mattei and Platikanova (2017) have documented evidence that product market competition is associated with lower precision in earnings forecasts, due to the increased uncertainty regarding future cash flows.

Perhaps a fundamental scepticism about the credibility of analysts' forecasts is that their forecasting behaviours are ultimately a product of personal judgements and incentives (Das et al. 1998; Clement 1999; Hong et al. 2000; Lim 2001; Chan et al. 2007; Bradley et al. 2017a; Horton et al. 2017; Merkley et al. 2017b). Prior literature argues and provides evidence implying that 
earnings forecasts are subject to optimism bias and herding behaviour on the part of financial analysts.

Since forecast accuracy is profoundly important to the career success of financial analysts (Mikhail et al. 1999; Lim 2001; Hong and Kubik 2003), analysts need to access as much information relevant to future earnings as possible, from various sources, to improve the quality of their earnings forecasts and consequently their career outcomes over the long run. Arguably, the most direct and relevant information source is the management, who have the most privileged access to all the first-hand information relevant to the future earnings of the company. Thus, prior literature has established that sell-side analysts have strong incentives to issue more optimistic earnings forecasts in order to retain their access to private information from the management (Das et al. 1998; Hong and Kubik 2003). Interestingly, Hong and Kubik (2003) find that, controlling for accuracy, analysts who are more optimistic relative to their peers are more likely to experience favourable career outcomes. Therefore, Lim (2001) argues that, for analysts, trading off management access against forecast accuracy, it is an optimal and rational strategy to issue positively biased earnings forecasts, and suggests that the magnitude of the bias is determined by the firm's information environment. In the context of the banking industry, Horton et al. (2017) reveal that financial analysts specialising in the banking sector are more likely to issue positively biased earnings forecasts for banks that could be prospective employers for them. Other sources of conflicts of interests that could bias analysts' earnings forecasts upward include their incentives to attract investment banking clients and generate trading commissions (Michaely and Womack 1999; Chan et al. 2007).

In parallel with the optimistic bias in the earnings forecasts, sell-side analysts also engage in herding behaviour due to career concerns (Hong et al. 2000; Clement and Tse 2005). Since the performance of financial analysts is reviewed on a relative basis, according to Hong and Kubik (2003), analysts with relatively more accurate forecasts are more likely to enjoy career progression. Consistent with the career-concern argument, Hong et al. (2000) find financial analysts, particularly those with limited experience and information access, are more likely to herd with other analysts by issuing earnings forecasts that are close to the consensus forecasts amongst their peers. In an investigation into the consequences of analysts' herding behaviours, Clement and Tse (2005) find that herding forecasts are less accurate than bold forecasts, suggesting that the latter convey more private and relevant information to investors.

Despite the aforementioned positive impact on corporate governance quality, analysts' intense monitoring may also create excessive pressure on managers, leading to suboptimal managerial 
decisions. For example, He and Tian (2013) document causal evidence that analyst coverage hinders firm innovations because managers feel pressured to meet short-term targets by cutting innovative projects, even if they could be value-enhancing in the long run.

The interplay between analysts and managers is further complicated by managers' strategic impression management (Cotter et al. 2006; Hilary 2006). On the one hand, managers have strong incentives to meet or beat analysts' earnings forecasts in order to earn higher stock returns and signal strong future economic prospects to investors (Bartov et al. 2002). On the other hand, Cotter et al. (2006) find that, to counterbalance the analysts' optimism in earnings forecasts, managers issue explicit earnings guidance in an attempt to manage the expectations of financial analysts and lead them towards more achievable earnings targets.

In the context of labour unions, Hilary (2006) suggests that, in order to improve the management's bargaining position against organised labour, managers purposefully preserve information asymmetry between employees and employers.

\subsubsection{Labour Unions}

Labour unions constitute a powerful primary stakeholder that resides internally within firms, exerting a strong influence over managerial decisions as well as external stakeholders such as creditors (Bronars and Deere 1991; Matsa 2010; Chen et al. 2012; Chyz et al. 2013; Chung et al. 2016; Bradley et al. 2017c; Huang et al. 2017; Cheng 2017; Campello et al. 2018; Hamm et al. 2018). The collective-bargaining power of labour unions crucially lies in their ability to initiate labour strikes, which can be extremely disruptive to firms' operations and costly to the employers (Ashenfelter and Johnson 1969; Schmidt and Berri 2004; Myers and Saretto 2016). The core agenda of labour unions is to use their collective-bargaining power to safeguard employees' interests and demand better welfare from the employers on behalf of individual employees (Freeman and Medoff 1979).

Theoretically, the seminal work by Freeman and Medoff (1979) proposed that there were "two faces" of labour unions. On the one hand, consistent with the "monopoly model", labour unions use collective-bargaining strategies, such as strikes, to extract economic rent by suboptimally pushing up wages and benefits (Lewis 1964; Freeman and Medoff 1979; Freeman 1981; Clark 1984; Tracy 1986). On the other hand, the "collective voice" view argues that labour unions can serve as an effective channel through which the employees can express their opinions and perform monitoring of the management (Freeman and Medoff 1979; Chyz et al. 2013; Lin et al. 2018). 
Empirically, previous studies have found evidence supporting both views. Consistent with the "monopoly model", prior literature has established a positive union effect on both wages, and non-wage items such as fringe benefits, consistent with rent extraction through collective bargaining (Lewis 1964; Freeman 1981; Freeman and Medoff 1984; Pencavel and Hartsog 1984; Card 2001). Meanwhile, several studies show that labour unions can deter opportunistic managerial behaviour through strong scrutiny (Chyz et al. 2013; Huang et al. 2017). For example, Chyz et al. (2013) find that labour unions significantly undermine managers' ability to engage in tax avoidance activities, while Huang et al. (2017) document that executive compensation is significantly curtailed in the presence of labour unions, suggesting that organised labour can improve corporate governance.

Despite the empirical support for both views on labour unions, prior literature has yet to reach a consensus on their aggregate economic effect (Clark 1984; Ruback and Zimmerman 1984; DiNardo and Lee 2004; Lee and Mas 2012). Specifically, the earlier work by Clark (1984) and Ruback and Zimmerman (1984) shows a negative union effect on firm performance and shareholders' wealth. By contrast, the latter two studies, by exploiting the natural experimental setting of union elections, suggest that the economic impact of labour unionisation on firm value is close to zero.

Nevertheless, the disruptions and uncertainties caused by labour unions are materially detrimental, particularly when they engage in extreme collective-bargaining activities, such as large-scale strikes. Becker and Olson (1986) find that a strike involving more than 1,000 workers destroys 4.1 per cent of shareholders' value, on average, which is equivalent to around $\$ 80$ million in 1980 prices $^{6}$. The negative effect also extends to the debtholders, as Campello et al. (2018) find that labour unionisation leads to a decline in bond values. As a result, unionised firms face a higher cost of capital in both the equity and debt markets (Chen et al. 2011; Cheng 2017). In addition, prior literature finds that union representation creates operational inflexibilities (Atanassov and Kim 2009; Chen et al. 2011) and hinders firm innovation (Bradley et al. 2017c).

To improve their bargaining position and mitigate strike risk, firms proactively make strategic corporate decisions. It is well documented that firms strategically adjust their capital structures by reducing cash holdings (Klasa et al. 2009) and increasing leverage (Bronars and Deere 1991;

\footnotetext{
${ }^{6}$ Recent anecdotal evidence suggests that labour strikes have become even more costly in more recent times. In 2008 , a 58 -day strike by 27,000 machinists at Boeing, the largest aircraft manufacturer in the world, caused $\$ 100$ million of losses per day in deferred revenue, and $\$ 2$ billion in lost profits. The share price also plummeted, by 56 per cent, to a five-year low during the strike period (Reuters 2008). For a more recent example, see footnote 4 for a description of the cost of the 2016 strike suffered by Verizon.
} 
Matsa 2010; Myers and Saretto 2016) to essentially shelter financial resources from organised labour. Furthermore, several studies find that unionised firms engage in "downward" impression management, disseminating less positive economic prospects by narrowly missing analysts' forecasts (Bova 2013) and strategically withholding good news (Chung et al. 2016) in order to undermine unions' desire to extract economic rent during labour contract negotiations. Therefore, Hilary (2006) argues that stronger labour power is associated with a higher degree of information asymmetry in the capital markets because managers have strong incentives to obfuscate information to preserve their bargaining position against labour unions.

\subsection{Hypothesis Development}

While both the "complementary" and "substitutive" roles of financial analysts are empirically supported in previous studies, it is unclear which role they primarily play in the context of organised labour. In this section, guided by the two roles that financial analysts play in the capital markets, we formulate competing hypotheses regarding analyst forecast quality in the presence of labour unions.

\subsubsection{Labour Unions and Financial Analysts: "Complementary Role"}

Assuming financial analysts primarily serve a "complementary role" in the context of unionised labour, labour unions could affect analyst forecast quality both directly through the "uncertainty" channel and indirectly through the "financial reporting" channel.

Directly, labour unions can bring substantial uncertainties to firms, on multiple fronts. To begin with, labour costs constitute a significant proportion of companies' total expenditure. For instance, in the manufacturing sector, where labour unions are more prevalent and active, the total payroll and benefits in 2008 were $\$ 784$ billion, more than four times of the total capital expenditures at $\$ 166$ billion, in the same year (Hamm et al. 2018). Knowing that labour expense is a sizeable component on the income statement, managers simply cannot afford to accept labour unions' wage demands in their entirety and will instead bargain with them to seek concessions with respect to wages (Klasa et al. 2009). As a result, it is impossible for either party, let alone external stakeholders such as financial analysts, to precisely predict, ex ante, what the labour costs will be in the future. Therefore, it is reasonable to argue that the collective bargaining of a labour union creates uncertainty in a firm's labour costs, which can have a material, if not substantial, impact on its profitability and ultimately bottom-line earnings per share (EPS). Consequently, the strong collective bargaining engaged in by organised labour 
makes it more difficult for financial analysts to predict future labour costs precisely, leading to less accurate and more dispersed earnings forecasts for unionised firms.

In addition to the uncertainty in labour costs, labour unions' ability to initiate large-scale labour strikes creates further uncertainties in businesses (Ashenfelter and Johnson 1969; Reder and Neumann 1980; Myers and Saretto 2016). Historically, 15 per cent of labour contract negotiations have ended in strikes (Tracy 1986). Prior economic and finance studies suggest that the financial position of the employers and labour market conditions significantly affect unions' strike decisions (Reder and Neumann 1980; Tracy 1986; Cramton and Tracy 1992; Klasa et al. 2009). Despite much scholarly effort looking into the determinants of labour strikes, however, predicting strike events is extremely challenging for financial analysts. This is because the decision to strike is not solely determined by the financial position of the employer, which analysts are typically good at evaluating. Reder and Neaumann (1980) argue that another factor is the bargaining styles of the negotiating parties, which again may vary across different industries. While it is true to say that a strike will normally take place in the middle of a labour dispute, calling a strike is not the only collective bargaining strategy organised labour can employ. Employees could continue to work under an expired contract during labour contract negotiations, which is known as a holdout (Cramton and Tracy 1992; Gu and Kuhn 1998). Therefore, even if there is serious tension between the employees and employers during negotiations, it is not a foregone conclusion that the employees will strike, which makes it even harder for financial analysts to predict such events. Furthermore, assuming analysts did have privileged access to private information that suggested a strike was imminent, the exact timing of the strike event would still be unknown and arguably random, at least from the perspective of the analysts. Moreover, even if analysts could precisely predict the timing, it would be unrealistic to assume they could, ex ante, accurately quantify and fully capture the economic consequences in their earnings forecasts for the company. While there is no doubt that strikes are extremely detrimental for employers, gauging the magnitude, in monetary terms, of the disruption and damage caused is challenging even expost. Generally, the cost of a strike is a function of the number of employees involved, the duration of the stoppage, and the final settlement reached by the two sides (Becker and Olson 1986). The reality that financial analysts cannot possibly foresee any of the information regarding a potential strike implies that the uncertainty posed by a labour union is unlikely to be precisely accounted for in earnings forecasts, thus leading to lower quality in earnings forecasts. 
Moreover, the existence of labour unions can be an obstacle that complicates the implementation of corporate policies and strategies, even though these decisions may well be value-creating for the shareholders. For example, organised labour can be very resistant to firms' restructuring decisions and cost-cutting strategies, which typically involve plant closures and labour layoffs (Atanassov and Kim 2009; Chen et al. 2011). Specifically, Atanassov and Kim (2009) demonstrate that strong unions intervene in the restructuring process and can effectively avert large-scale layoffs and plant closures, thus creating operational inflexibilities in the implementation of restructuring decisions. Labour unions can also affect firms' innovation strategies. Bradley et al. (2017c) suggest that labour unions undermine firms' efforts at research and development, hindering their innovation. Therefore, we argue that the operating inflexibilities brought about by labour unions cause uncertainties in the implementation of key corporate strategies, which can have profound implications for firms' prospects and shareholders' wealth (John et al. 2015). Although financial analysts pay close attention to companies' strategies and policies through corporate disclosure and announcements, the extent to which employees will cooperate with the management in the delivery of those strategies is arguably difficult for financial analysts to gauge as an external party.

Meanwhile, labour unions could also indirectly affect analysts' forecast quality through the financial reporting channel, due to managerial obfuscation. To improve their bargaining position and undermine union power, managers proactively engage in a range of strategic corporate decisions to shelter financial resources and obfuscate their true financial position and earnings prospects from organised labour (DeAngelo and DeAngelo 1991; Hilary 2006; Klasa et al. 2009; Matsa 2010; Bova 2013; Chung et al. 2016). Specifically, to shelter financial resources, firms strategically adjust their capital structure by holding less cash (Klasa et al. 2009) and increasing leverage (Matsa 2010; Myers and Saretto 2016). In addition to altering the data regarding their current financial position, managers also proactively engage in impression management to project a less positive view of their future earnings by manipulating earnings (DeAngelo and DeAngelo 1991; Hamm et al. 2018), narrowly missing analysts' forecasts (Bova 2013) and withholding good news (Chung et al. 2016). It is worth mentioning that Hamm et al. (2018) argue that managers, facing a trade-off between sheltering resources from employees and signalling job security to employees, choose to smooth earnings optimally. Irrespective of the direction of the earnings management (i.e., whether deflated or smoothed), the managers are artificially manipulating the actual earnings, which incorporates distortion and noise into the accounting information. Therefore, the aforementioned strategic corporate reactions generally lead to a poorer information environment (Hilary 2006), and project a misleading and opaque 
image to financial analysts regarding the firms' prospects. Assuming financial analysts predominantly play a "complementary role" (Lang and Lundholm 1996; Altınkılıç et al. 2013), we would expect them to make their earnings forecasts based on all the publicly available information disclosed by managers. Given the poorer information environment in the presence of labour unions, we conjecture that analysts' earnings forecasts will be less accurate and more dispersed in firms facing strong union representation.

Critically, while we admit that the "uncertainty" and "financial reporting" channels are not mutually exclusive, and could simultaneously affect financial analysts' earnings forecasts in the same direction, the financial reporting channel is ultimately contingent on managers' discretion and efforts to preserve their bargaining position against organised labour. Irrespective of the managerial efforts to preserve information asymmetry, we argue that the presence of a labour union itself is an inherent source of uncertainty, difficult for financial analysts to capture fully in their earnings forecasts.

Taking these arguments together, assuming financial analysts primarily play a "complementary role", they are likely to be affected by the poor information environment and significant uncertainty regarding human capital in unionised firms (Zhang 2006b; Amiram et al. 2018). Hence, we propose our main hypothesis:

Hypothesis 1a (Complementary Role): Labour unionisation is negatively (positively) associated with earnings forecast accuracy (dispersion).

\subsubsection{Labour Unions and Financial Analysts: "Substitutive Role"}

Alternatively, assuming financial analysts primarily play a "substitutive role", they should proactively engage in original research in the firms they are following, and produce new and value-relevant information that would not otherwise be available to the investors (Asquith et al. 2005; Barron et al. 2008; Barron et al. 2017; Bradshaw et al. 2017).

The informational role financial analysts play in capital markets is well recognised in the analyst literature (Chen et al. 2010; Bradshaw et al. 2017; Huang et al. 2017). Focusing on the content of analyst reports, Asquith et al. (2005) present evidence that they are informative to investors, particularly in the case of downgrades. In an investigation into analysts' behaviour after significant forecast failures, Barron et al. (2008) show that analysts are motivated to dedicate more effort to original research, and have the ability to generate private information to improve their future earnings forecasts. Recent studies suggest that financial analysts continue to produce 
valuable information for the market, even under adverse circumstances. When uncertainty increases or the information environment deteriorates, analysts put more focus on information discovery, and their outputs become more informative, because investors have a greater demand for high-quality information about firms' future earnings prospects (Loh and Stulz 2018; Jennings 2019).

If we assume analysts predominantly engage in the "substitutive role", in response to the heightened uncertainty in the workforce and deterioration of the information environment in unionised firms, we would expect them to devote more resources and effort to generating firsthand information about the underlying economics of unionised firms, knowing that such information will be greatly valued by the investors (Loh and Stulz 2018; Jennings 2019). By putting more effort into producing original reports, financial analysts may also be rewarded in terms of reputation enhancement and career progression.

Not only do financial analysts have incentives to provide new information in the context of organised labour, but they are also capable of and ideally positioned to produce valuable information highly relevant to a firm's future performance (Loh and Stulz 2018; Huang et al. 2018; Jennings 2019). Firstly, financial analysts have exclusive access to information from multiple channels other than public disclosure (Huang et al. 2018). When the information disclosed by managers is less credible, or limited, they can generate valuable information from sophisticated research and private interactions with employees, customers and competitors, in order to form a comprehensive and consistent picture regarding the underlying economics of the company in question (Soltes 2014; Huang et al. 2018) ${ }^{7}$. For example, when there is greater uncertainty about firms' human capital, and more complicated employee-employer relations, financial analysts may obtain valuable insights into employee wellbeing through interactions with rank-and-file employees. Secondly, financial analysts can use their skills and financial expertise to analyse and aggregate financial and non-financial information from multiple sources, providing highly informative outputs to investors (Healy and Palepu 2001; Bradshaw 2011; Dhaliwal et al. 2012; Huang et al. 2018). In addition, financial analysts tend to specialise in a number of firms within a particular industry, making them experts of a certain industry. Therefore, they are likely to possess firm or industry-specific knowledge and insights that may help them to generate

\footnotetext{
${ }^{7}$ Despite the passing of Regulation Fair Disclosure (RegFD) by the Securities and Exchange Commission (SEC), which was specifically designed to tackle concern over "offline" interaction between financial analysts and management, Soltes (2014) finds that financial analysts continue to access material information from management privately in the post-RegFD period.
} 
valuable information for investors, with respect to the underlying economics and predicted profitability of particular firms (Bradley et al. 2017a; Jennings 2019).

Previous literature has also produced empirical evidence consistent with financial analysts providing incremental information to the capital markets (Chen et al. 2010; Altınkıliç et al. 2013; Bradley et al. 2017a; Loh and Stulz 2018; Huang et al. 2018; Jennings 2019). By exploiting the setting of economically bad times, Loh and Stulz (2018) show that financial analysts are able to provide more valuable information and accurate forecasts amid heightened uncertainty. In a similar vein, Jennings (2019) finds that financial analysts generate more informative analyst research following accusations of managerial misconduct, which significantly undermine the credibility of management-provided information and drive up the demand for analyst services. In other words, financial analysts are capable of producing new information, even when managerial disclosures are less credible or when uncertainty is systematically higher.

Similarly, knowing that investors have a greater information demand in the context of increased uncertainty regarding human capital, we argue that analysts have greater incentives to devote more resources and effort to generating more value-relevant information for unionised firms specifically, in order to meet investors' information demands. As a result, we predict that financial analysts' earnings forecast quality may be higher for unionised firms due to the increased and dedicated efforts made by the sell-side analysts. Hence, we propose a competing hypothesis H1b below.

Hypothesis 1b (Substitutive Role): Labour unionisation is positively (negatively) associated with earnings forecast accuracy (dispersion).

Despite the potentially poorer financial transparency and information environment in unionised firms, it is plausible that financial analysts, as sophisticated information users and experts in the industries they specialise in, may well be capable of detecting earnings manipulation and deciphering the underlying earnings prospects. For example, Yu (2008) argues that financial analysts have the financial expertise to detect earnings management, and finds that analyst coverage significantly reduces earnings management. Focusing on non-GAAP earnings reporting, and comparing that of managers and analysts, Bentley et al. (2018) reveal that financial analysts scrutinise managers' non-GAAP metrics and filter out earnings components that are deemed less relevant. This evidence implies that financial analysts have the ability to assess and distinguish the quality of information supplied by managers. Therefore, given analysts' financial sophistication 
and firm/industry expertise, we propose a null hypothesis that financial analysts' earnings forecasts are not affected by labour unions ${ }^{8}$.

Hypothesis 1 $_{\text {null: }}$ Labour unionisation is not associated with earnings forecast accuracy/dispersion.

\section{Data and Methodology}

\subsection{Data Sources and Sample Construction}

Our study uses data from multiple sources. We obtain the labour unionisation data for the period of 1983-2015 from the Union Membership and Coverage Database (UMCD) maintained by Hirsch and Macpherson $(2003)^{9}$. Our sample period starts in 1983, the first year in which industry-level unionisation data were reported. We access all the analyst earnings forecast data from the Detailed History File of the Institutional Brokers' Estimate System (I/B/E/S), for 1983 to 2015. Consistent with prior analyst studies (Zhang 2006a; Dhaliwal et al. 2012), we use the Detailed History File instead of the Summary History File to mitigate concerns over stale forecasts and rounding errors (Diether et al. 2002). Additional firm-level financial information and stock return data are collected from Compustat and the Centre for Research in Security Prices (CRSP). After merging the different databases, our baseline sample consists of 93,530 firm-year observations from 12,744 unique firms, spanning over 30 years from 1983 to 2015.

\subsection{Main Variables}

\subsubsection{Labour Unionisation Rate}

A common challenge in union studies is the lack of a comprehensive firm-level unionisation database since it is not mandatory for firms to disclose such information (Klasa et al. 2009; Chen et al. 2011). Following prior literature, we obtain the industry-level unionisation rate from the UMCD, as mentioned above, as a proxy for the union strength at the firm level (Hilary 2006; Klasa et al. 2009; Matsa 2010; Chen et al. 2011; Chen et al. 2012; Chyz et al. 2013; Huang et al. 2017; Hamm et al. 2018). ${ }^{10}$ Specifically, the labour unionisation rate (UNION) is measured as the

\footnotetext{
${ }^{8}$ It is also possible that the net effect of the "dual roles" is close to zero, in which case the incremental value of original research is offset by the overall poorer information environment and uncertainties in unionised firms, resulting in no systematic difference in forecast quality between unionised and non-unionised firms.

9 The union data are downloaded from http://www.unionstats.com. Data on the unionisation rates are drawn from the Current Population Survey and compiled annually by Hirsch and Macpherson (2003). For more information regarding the construction of this comprehensive database, please see Hirsch and Macpherson (2003).

${ }^{10}$ The use of the same union database (1) allows us to study the research question based on a larger sample of firms from the whole spectrum of industries, hence increasing the generalisability of our results, and (2), more importantly,
} 
percentage of workers who are represented by labour unions through collective-bargaining agreements within a three-digit Census Industry Classification (CIC) industry ${ }^{11}$ in a given year. The unionisation rate (UNION) across all CIC industries over the period of 1983-2015 is 11.82 per cent, which is highly comparable to prior literature (Chen et al. 2011; Huang et al. 2017).

\subsubsection{Analyst Forecast Variables}

In this study, we focus on two of the most common earnings forecast properties in the financial analyst literature, forecast error and forecast dispersion (Lang and Lundholm 1996; Chen et al. 2017; Mattei and Platikanova 2017). Consistent with previous studies (Lang and Lundholm 1996; Clement 1999; Duru and Reeb 2002; Dhaliwal et al. 2012), we use all the earnings forecasts issued by financial analysts in the fiscal year for a given company to calculate these two variables. Specifically, following Dhaliwal et al. (2012), forecast error (FERROR) is defined as the average of the absolute errors of all forecasts scaled by the share price:

$F_{E R R O R}=\frac{1}{N} \sum_{j=1}^{N} \frac{\mid \text { Forecasted EPS } S_{i, t, j}-\text { Actual EPS }_{i, t} \mid}{{\text { Share } \text { Price }_{i, t}}}$

where subscripts $i$, $t$, and $j$ denote firm $i$, year $t$, and forecast $j$, respectively. Similarly, consistent with Lang and Lundholm (1996), forecast dispersion (FDISPER) is computed as the standard deviation of all the forecasts, deflated by the share price:

FDISPER $R_{i, t}=\frac{\text { Standard Deviation of Forecasted } E P S_{i, t}}{\text { Share Price }}$

where subscripts $i$ and $t$ again denote firm $i$ and year $t$, respectively. In calculating the standard deviation, we include companies that are followed by at least two financial analysts in the year in question (Chen et al. 2017). Since both measures are scaled by the share price, to avoid extremely small values in the denominator and to make sure our results are not driven by small stocks, we exclude observations with a share price below one dollar (Hope 2003b; Horton et al. 2017).

\subsection{Summary Statistics}

Table 1 presents the summary statistics for our baseline sample. The mean (median) unionisation rate (UNION) is 9.6 (4.8) per cent, which is slightly lower than that in the original union dataset. This is because our sample is essentially made up of $\mathrm{I} / \mathrm{B} / \mathrm{E} / \mathrm{S}$ firms that are covered by financial

provides consistency of union data, enabling direct comparison of our findings with prior studies (Hilary 2006; Chen et al. 2011; Bova 2013; Hamm et al. 2018).

${ }^{11}$ We use the crosswalk provided by the U.S. Census Bureau to convert the CIC industry codes into SIC codes and thereby merge datasets from other sources. The crosswalk file can be accessed at https://www.census.gov/topics/employment/industry-occupation/guidance/code-lists.html. 
analysts, who are less likely to follow and make earnings forecasts for unionised firms (Hilary 2006). The mean (median) value of forecast error (FERROR) is $0.052(0.007)$ and the mean (median) value of forecast dispersion (FDISPER) is 0.031 (0.006). The descriptive statistics for both analyst forecast measures are highly comparable to those reported in Lang and Lundholm (1996). For example, the mean and median values of forecast error, which is the inverse measure of forecast accuracy, in Lang and Lundholm (1996) are 0.042 and 0.008, which are similar to the values of 0.052 and 0.007 in our sample. The mean (median) value of analyst coverage (ANALYST_NUM) is 29.882 (18.000), suggesting that each firm-year observation is followed by almost 30 financial analysts on average. The variable definitions are provided in the appendix.

\section{***Insert Table 1 here***}

\subsection{Empirical Models}

To examine the influence of labour unions on the quality of analysts' forecasts, we estimate the following model:

$$
\begin{aligned}
& \text { FORECAST }_{i t}=a+\beta_{1} \text { UNION }_{j t}+\beta_{2} \text { SIZE }_{i t}+\beta_{3} \text { MTB }_{i t}+\beta_{4} \mathrm{LOSS}_{i t}+\beta_{5} \mathrm{EARNSURP}_{i t}+\beta_{6} \mathrm{LEV}_{i t} \\
& +\beta_{7} R D \_E X P_{i t}+\beta_{8} A G E_{i t}+\beta_{9} Z S C O R E_{i t}+\beta_{10} S D \_I N C O M E_{i t}+\beta_{11} S D \_S T K_{i t} \\
& +\beta_{12} \text { ANALYST_NUM }{ }_{i t}+\text { Firm FE }+ \text { Industry } \times \text { Year FE }+ \text { State FE }+\varepsilon_{i j t}
\end{aligned}
$$

We run Model (3) separately for each of the forecast quality measures, i.e., forecast error (FERROR) and forecast dispersion (FDISPER), as our dependent variable. The variable of interest is the unionisation rate (UNION). Following Mattei and Platikanova (2017), we also control for a vector of firm characteristics that may affect analysts' forecast quality. Apart from conventional firm characteristics such as size and financial position, we also control for analyst coverage (ANALYST_NUM), as a proxy for the general information environment (Hilary 2006; Chang et al. 2006; Tan et al. 2011; Armstrong et al. 2012; Amiram et al. 2016). All variables are defined in the appendix.

Since our key variable, UNION, is measured at the industry level, our estimates are unlikely to be driven by reverse causality, because there is little economic reason to believe that the properties of analyst forecasts at the firm level would affect the unionisation of the workforce across the industry. While reverse causality is less of a concern, it is still possible that our estimates may suffer from omitted variable bias. Therefore, we include a series of fixed effects to alleviate endogeneity concerns. To this end, we include firm fixed effects to control for time-invariant firm characteristics that may affect analyst forecast properties in all specifications. In addition, 
since our variable of interest is measured at the industry-year level, we include industry-year fixed effects to control for time-varying industry factors that may be correlated with our key variable, the unionisation rate $(U N I O N)$. This specification ensures that our results are not confounded or spuriously driven by changes in other unobservable industry-level factors. Finally, we include state fixed effects to account for state-level economic and legal conditions, such as RTW] legislation, which can seriously undermine unions' bargaining power (Ellwood and Fine 1987; Chen et al. 2011). Consistent with prior literature (Chen et al. 2011; Chino 2016; Huang et al. 2017), standard errors are clustered at the CIC industry level, which is considered more conservative than clustering at the firm level. Chen et al. (2011) suggest that clustering at the industry level not only addresses the concern of serial correlation within a firm, but also within industry groupings, important given that our variable of interest (UNION) is at the industry level. For robustness, we also cluster standard errors at both industry and year levels to address potential serial correlations within industry as well as year groups (Petersen 2009; Chyz et al. 2013).

\section{Empirical Findings}

\subsection{Baseline Results}

\subsubsection{Labour Unions and Forecast Accuracy}

Table 2 presents the results of our baseline regressions on the influence of labour unions on analyst forecast accuracy. We find consistent evidence that the labour unionisation rate is associated with higher (lower) forecast error (accuracy), which points to sell-side analysts playing the "complementary role". The estimates of the control variables are generally in line with prior literature in terms of having the expected signs. For example, SIZE is negatively associated with forecast error, consistent with larger firms, in general, having better information environments, while LOSS is positively significant since it is more difficult to estimate future earnings for lossmaking firms. In addition to our control variables, to alleviate endogeneity concerns, we include firm fixed effects, to control for unobservable firm characteristics that may affect analysts' ability to accurately forecast earnings, across all OLS specifications. In addition, we include year fixed effects (Columns 1 and 4), industry-year fixed effects (Columns 2, 3, 5 and 6) and state fixed effects (Columns 3 and 6), to mitigate the concern of omitted variable bias. Since the variable of interest, UNION, is an industry-level variable, we cluster standard errors at the industry level to address serial correlation at that level, across all OLS regressions. For robustness, standard errors 
are clustered at both the industry and the year level in Columns 4-6 (Petersen 2009; Chyz et al. 2013). UNION remains positive and statistically significant across all specifications.

*** Insert Table 2 here***

\subsubsection{Labour Unions and Forecast Dispersion}

We repeat our analysis using forecast dispersion (FDISPER) as the dependent variable, and we document a positive relationship between unionisation rates and analysts' forecast dispersion, across all specifications. Given the greater ex-ante uncertainty in unionised firms and potentially poorer information environment, financial analysts, primarily playing a "complementary role" in the markets, would be less likely to reach a consensus with regard to the firms' future economic performance (Imhoff and Lobo 1992; Lang and Lundholm 1996). In other words, had financial analysts, on aggregate, engaged more in the "substitutive role" by conducting original research into these unionised firms, as sophisticated information users, they should have been able to gather the relevant intelligence and gain a better idea of what the future earnings were likely to be, at least within a reasonable range.

***Insert Table 3 here***

In support of our Hypothesis 1a, the results in Tables 2 and 3 indicate that the labour unionisation rate is associated with lower forecast accuracy and higher forecast dispersion, suggesting that financial analysts are affected by the presence of labour unions. We interpret these results as evidence consistent with financial analysts predominantly playing a "complementary" rather than "substitutive" role in the capital markets.

\subsection{Verification of Channels: Uncertainty versus Financial Reporting Quality}

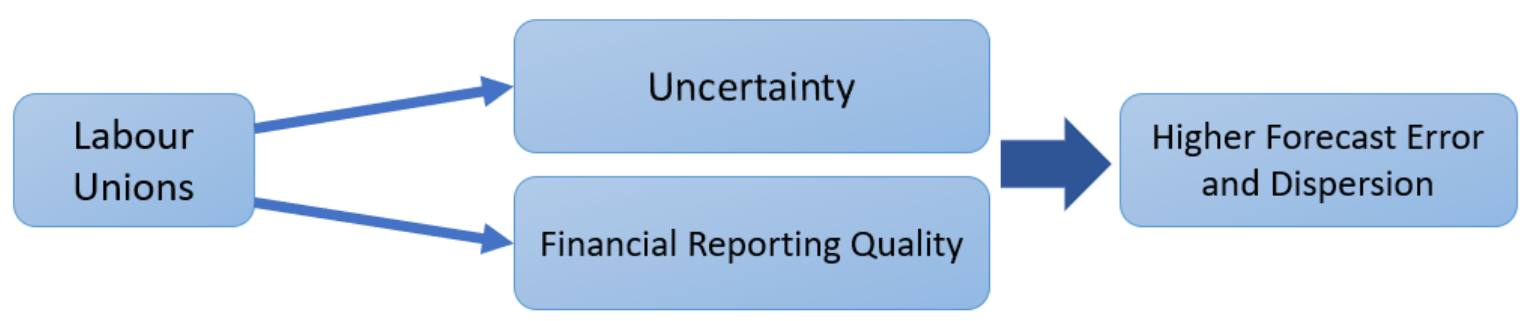

Figure 1 Labour Unions and Analyst Forecasting: Plausible Channels

So far, our baseline results suggest that financial analysts are negatively affected by labour unions, in the form of lower forecast accuracy and higher forecast dispersion. While this result is 
consistent with our $\mathrm{H1}$ a, it is unclear whether this effect occurs through the "financial reporting channel" or the "uncertainty channel".

Prior union literature suggests that unionised firms engage in downward earnings management and information obfuscation in order to mitigate strike risk and improve their bargaining position against labour unions (Liberty and Zimmerman 1986; Hilary 2006; Bova 2013; Chung et al. 2016). Therefore, one may reasonably argue that the union effect on analysts' forecast quality we document in our baseline models could be attributable to poorer financial reporting quality due to managerial obfuscation, rather than "uncertainty" brought about by labour unions. Nonetheless, we argue that the two channels are not mutually exclusive and predict that the two channels could simultaneously impact the analyst forecast properties.

To disentangle the two channels and, more importantly, make sure that the labour union effect on analysts' forecasting is not solely driven by a poor information environment, we further test the relationship between labour unions and analyst forecasting by controlling for financial reporting quality, given that financial analysts rely heavily on financial information to forecast future earnings. We predict that, after controlling for financial reporting quality, the key variable, UNION, will remain positive and statistically significant.

The rationale behind this additional test is that, assuming financial reporting quality is the only channel through which labour unions can affect analysts' earnings forecast properties, controlling for financial reporting quality will essentially make the UNION variable insignificant, since the entire union effect will be subsumed by the additional control variables for financial reporting quality. In other words, if the UNION variable is persistently significant after controlling for financial reporting quality, this will imply that labour unions have an incremental effect on analysts' forecast quality, on top of the unions' adverse influence on the information environment. Effectively, we disentangle the two plausible channels and can, therefore, interpret with reasonable confidence that this incremental effect is due to union presence imposing inherent uncertainties on firms.

\subsubsection{Proxies for Financial Reporting Quality}

To account for the financial reporting channel, in our further analysis, we include three variables to capture the quality of financial reporting: accrual-based earnings management (Kothari et al. 2005), real earnings management (Roychowdhury 2006; Cohen et al. 2008) and financial statement comparability (De Franco et al. 2011). Intuitively, both accrual-based and activitiesbased earnings management essentially reduce earnings quality, and therefore the 
informativeness of accounting information, whereas financial statement comparability benefits information users by lowering the costs of processing financial information, and enhancing understanding of financial information across comparable peers, which is particularly useful for financial analysts (De Franco et al. 2011; Kim et al. 2016).

Specifically, to capture the level of accrual-based earnings management, we follow Kothari et al. (2005) and estimate the absolute value of the performance-matched discretionary accruals $\left(A B S \_D A\right)$. Following Roychowdhury (2006), we estimate the abnormal levels of cash flow from operations ( $\left.R \_C F O\right)$, discretionary expenses $\left(R \_D I S X\right)$ and production costs $\left(R \_P R O D\right)$ to proxy for the magnitude of real activities manipulation. Then, consistent with Cohen et al. (2008), we construct a comprehensive measure to capture the overall level of real earnings management (Combined_RAM) by combining the three individual variables ( $\mathrm{R} \_C F O, R \_P R O D$ and $\left.R \_D I S X\right)$. Finally, as the third proxy for financial reporting quality, we use the financial statement comparability score developed by De Franco et al. (2011) ${ }^{12}$, which measures the closeness of the accounting systems of two firms. The underlying rationale behind this measure is that, for any given set of economic events, firms are more likely to produce similar financial statements if they have more comparable accounting systems. Essentially, the main comparability measure $(\operatorname{CompAcct4})^{13}$ is defined as the average comparability score of the four most comparable peers of a particular firm in a particular year.

\subsubsection{Incremental Effect of Union Representation}

Table 4 reports the results after controlling for the three abovementioned proxies for financial reporting quality, first of all separately: (1) accrual-based earnings management (Columns 1-3), (2) real earnings management (Columns 4-6) and (3) financial statement comparability (Columns 79), and then jointly (Columns 10-12), using different sets of fixed effects ${ }^{14}$. In addition, we include all the other control variables from the original model described in Equation (3), for consistency.

Panel A presents the relationship between the labour unions and analyst forecast accuracy (FERROR) after controlling for financial reporting quality. It is critical to note that our variable of interest, UNION, remains positive and statistically significant after controlling for the quality

\footnotetext{
12 The dataset can be accessed at Rodrigo Verdi's personal website (http://mitmgmtfaculty.mit.edu/rverdi/). Detailed descriptions and construction of the data are presented in De Franco et al. (2011).

${ }^{13}$ Our results are robust to an alternative comparability measure (CompAcct10) based on the average comparability value of the 10 most comparable firms.

${ }^{14}$ After matching our baseline sample with all three financial reporting quality variables, our sample size drops to 27,380 . Standard errors are clustered at both the industry level and the year level, which is considered more rigorous.
} 
of financial reporting to take into account the effect of managerial obfuscation in the presence of labour unions. In line with our prediction that earnings management will distort accounting information and lower the informativeness of accounting information (Dechow et al. 2010), both accrual-based earnings management $\left(A B S \_D A\right)$ and real earnings management (Combined_R $\left.A M\right)$ are significant and positively associated with forecast errors. In contrast, financial statement comparability (CompAcct4) is associated with significantly lower earnings forecast errors, which is consistent with the finding of De Franco et al. (2011). All three financial reporting quality variables are consistently and highly significant at the 1 per cent level, with expected signs across all specifications, confirming that labour unions can affect analysts' forecasts through the "information channel". Importantly, the persistent significance of our variable of interest UNION, after taking into account the financial reporting quality in unionised firms (Hilary 2006), suggests that labour unions do have an incremental effect on financial analysts' forecast precision. Similarly, as demonstrated in Panel B, we document a significantly positive union effect on earnings forecast dispersion (FDISPER) after including the additional controls for financial reporting quality.

While the information channel is indeed a plausible channel whereby managers strategically preserve information asymmetry to improve their bargaining position against union representation, our results suggest that managerial information obfuscation is not the only channel through which labour unions can influence analysts' forecast quality. We interpret this incremental union effect as evidence consistent with labour union representation inducing significant uncertainty in businesses, thus supporting our "uncertainty" conjecture. We argue that the very existence of a labour union itself constitutes a material source of uncertainty in human capital, which cannot be precisely modelled in analysts' earnings forecasts. Therefore, in light of the added uncertainties created by labour unions, analysts' earnings forecasts tend to be less accurate and more dispersed. Unlike the information channel, which relies on managers' efforts at strategic obfuscation of their financial position (Liberty and Zimmerman 1986; Hilary 2006; Bova 2013; Chung et al. 2016), our results offer a parallel and yet more direct channel, whereby union presence itself is a source of uncertainty that can directly affect analysts' forecast quality. Importantly, unlike Loh and Stulz (2018) and Jennings (2019), our results suggest that, in the context of union representation, financial analysts predominantly use the publicly available information, instead of exerting much-needed effort for unionised firms, where human capital uncertainty is inherently higher.

${ }^{* * *}$ Insert Table 4 here*** 


\subsection{Right-to-Work (RTW) Legislation}

An underpinning assumption behind the union effect is that our results are driven primarily by the enhanced bargaining power of the employees. Following this logic, the union effect on financial analysts should be more pronounced when union power is stronger, and moderated when unions' bargaining ability is undermined. Following prior union literature (Chen et al. 2011; Campello et al. 2018), we exploit the exogenous variation in union power at the state level due to RTW legislation in the U.S., which seriously undermines labour unions' bargaining power (Ellwood and Fine 1987). Specifically, we partition our sample into RTW firms and non-RTW firms based on whether their headquarters are located in a state that has enacted the RTW law. We expect the relationship between labour unionisation and analysts' forecast quality to be stronger for firms based in non-RTW states, where unions enjoy greater bargaining power.

Table 5 reports the findings of the subsample analysis comparing RTW and non-RTW states. In line with our prediction, we find that the union effects on both forecast error (FERROR) and forecast dispersion (FDISPER) are positively significant in the non-RTW group (Columns 1-3 and Columns 7-9). In contrast, the insignificant results for the UNION variable, for both forecast properties, in the RTW group (Column 4-6 and Columns 10-12) suggest that labour unions have little influence on analyst forecast quality in RTW states where unions' power is profoundly weakened. Our subsample analysis based on this exogenous variation in labour unions' bargaining power supports our prediction that financial analysts' forecast quality is significantly affected only when labour unions possess substantive bargaining power. This is because greater union power is likely to introduce more uncertainty and trigger more managerial efforts to preserve information asymmetry. If financial analysts are indeed primarily playing the role of "information disseminators", their forecast quality is likely to be impacted to a greater extent. Therefore, this cross-sectional analysis also lends further assurance that our main results are indeed driven by the bargaining power of the labour unions rather than anything else.

\section{***Insert Table 5 here***}

\subsection{Role of Labour Skills}

We further study how labour skills may affect the relationship between organised labour and analysts' forecast quality. Prior literature in labour economics argues that low-skilled workers tend to benefit most from labour unions, in terms of both pay improvement and job security (Farber and Saks 1980; Freeman 1980; Lewis 1986; Card 1996). Compared with high-skilled employees, low-skilled employees are typically at the bottom of the earnings distribution within 
the firm, and are exposed to significantly higher unemployment risk (Farber and Saks 1980; Akerlof and Yellen 1988). Given the lower pay and higher unemployment risk, low-skilled workers are more reliant on labour unions to safeguard their jobs and negotiate higher wages on their behalf. To meet the higher expectations and demands from their union members, labour unions representing low-skilled workers are more likely to engage in collective-bargaining activities and pursue their agenda aggressively, for example, by initiating large-scale strikes. Thus, we predict that the union impact on analyst forecast quality should be stronger in low-skilled industries, where labour unions are expected to play a greater role and strike risk is perceived to be higher.

To conduct our analysis, we partition our sample into high-skill and low-skill firms based on labour skills. To proxy for the level of labour skills, we use an industry-specific Labor Skill Index (LSI), following Ghaly et al. (2017). Essentially, the LSI captures the weighted average skill level of the occupations within an industry, based on data from the Occupational Employment Statistics (OES) and O*NET program compiled by the U.S. Department of Labor. Table 6 presents the results of this subsample analysis.

In contrast to the insignificant results for firms in high-skilled industries, we find that the union effect on forecast accuracy is statistically significant in firms that rely heavily on a low-skilled workforce, which is consistent with firms in low-skilled industries facing stronger collective bargaining and being more prone to strike threats. As for forecast dispersion, we do find a significant result for the low-skilled subgroup in Column 7 and an insignificant result for the high-skilled group with the same specification (Column 10). However, the UNION variable is insignificant for the low-skilled subgroup in Columns 8 and 9, under the alternative specifications. One possible reason for the unsystematic difference in terms of forecast dispersion between the low-skilled and high-skilled industries is that high-skilled industries tend to have higher asset intangibility, which may also lead to larger discrepancies in analysts' forecasts due to the difficulty of evaluating intangible assets.

***Insert Table 6 here***

\subsection{Mitigating Role of Labour Costs Information}

Because of unions' agenda of pushing for higher salaries for employees, unionised firms are inevitably exposed to considerable uncertainties in labour costs, which significantly undermine financial analysts' ability to predict those costs, which represent a major expenditure component of the income statement and ultimately the bottom-line earnings figure in their forecasts. If 
financial analysts do indeed predominantly rely on readily available information in the markets (complementary role) rather than proactively collecting new information from original research (substitutive role), it would be reasonable to assume that they do not obtain wage data unless companies voluntarily disclose such information.

Therefore, we argue that information on labour costs would be extremely valuable and particularly relevant in the context of unionised firms, setting a good benchmark for the prediction of future labour costs. We predict that the availability of labour cost information would significantly improve analysts' capability to predict future labour costs and hence mitigate the union effect on analyst forecast quality. We thus collect information on labour-related expense (XLR) on Compustat and create a dummy variable XLR_Dummy, equal to one for the observations where the variable XLR is available and zero where it is missing ${ }^{15}$. Thus, we split our sample based on the availability of labour costs.

Table 7 reports the results for the two subgroups: (1) firms disclosing labour costs (Columns 1-3 and 7-9) and (2) firms not disclosing labour costs (Columns 4-6 and 10-12). While the union effect on both analyst forecast quality proxies persists for firms that do not disclose labour cost information to the market, we find that the UNION variable becomes insignificant for firms that do disclose such information, in all specifications, which supports our conjecture that the availability of wage data will significantly mitigate the union effect on forecast quality by improving analysts' ability to predict future labour costs, a major component of expenses and value-relevant information for unionised firms.

The interpretation of this finding is two-fold. Firstly, this result further supports the notion of a predominantly "complementary role” being played by sell-side financial analysts. By confirming the crucial role of labour costs, our results imply that financial analysts do rely on publicly disclosed information such as labour costs, as opposed to generating such information through proactive research, even though, intuitively, labour expenses would be very informative in the context of unionised firms. Secondly, the mitigating effect of labour cost information is also consistent with our argument that labour unions affect analysts' forecast quality by causing

\footnotetext{
${ }^{15}$ Since it is not mandatory for firms to disclose information on labour costs such as wages and salaries, in our final sample about 7 per cent of the observations have wage information (XLR), which is similar to Hamm et al. (2018).
} 
significant uncertainty in labour costs, therefore lending additional support to our "uncertainty channel"16.

\section{***Insert Table 7 here***}

\subsection{Strategic Optimism Bias}

So far, our analyses have mainly focused on how organised labour affects analysts' forecasts in terms of accuracy and dispersion. Yet, another key dimension of analysts' behaviour that is worth investigating is their optimism bias. Prior literature has established that they are more likely to issue positively biased forecasts when there is significant uncertainty regarding a firm's future profitability (Das et al. 1998; Lim 2001; Zhang 2006a; Bradshaw 2011). By issuing more favourable earnings forecasts, financial analysts can maintain access to private information from management ${ }^{17}$. Meanwhile, financial analysts may also be motivated to be positively biased due to career concerns (Hong and Kubik 2003; Horton et al. 2017). For example, Hong and Kubik (2003) discover that optimistic analysts are more likely to achieve career advancement, after controlling for forecast accuracy.

Building on this view, we argue that financial analysts will behave more strategically with respect to their earnings forecasts in response to heightened uncertainty in human capital. Knowing that their forecasts are more likely to be inaccurate due to the uncertainty and complexity within unionised firms, they will rationally choose to issue more optimistic forecasts in order to maintain access to private information and mitigate their career concerns at the same time (Das et al. 1998; Lim 2001). In other words, if financial analysts are indeed primarily playing a "complementary role", we would expect their earnings forecasts to be, on average, more optimistically biased for unionised firms, whose earnings are less predictable.

To test our conjecture, we construct an indicator variable, Optimism_Bias, which takes the value of one if the estimated EPS is larger than the actual EPS for the firm-year observation, and zero otherwise. Specifically, we run probit and logit models ${ }^{18}$ with Optimism_Bias as our dependent

\footnotetext{
${ }^{16}$ Since one may rightly argue that the disclosure of labour costs is an additional piece of information for financial analysts, this could also be considered evidence in favour of the "information channel". We admit that this test cannot completely disentangle the two channels and therefore serves only as suggestive evidence of the "uncertainty channel".

${ }^{17}$ Both Mayew (2008) and Soltes (2014) suggest that financial analysts continue to access value-relevant information through private interactions with management, even after the enforcement of RegFD in 2000.

${ }^{18}$ Since our dependent variable (Optimism_Bias) is a binary variable, we estimate our probit/logit models without firm fixed effects (Wooldridge 2010). Instead, we use industry-year fixed effects to account for time-varying industry-specific characteristics. For brevity, the results of the logit models are not reported.
} 
variable and UNION as our key independent variable, to test the relation between labour unionisation and analysts' propensity to issue optimistic forecasts. For robustness and easier interpretation, we repeat our analysis with an alternative variable of interest, High_UNION, a dummy variable equal to one if UNION is above sample median.

As presented in Table 8, the coefficients on both UNION (Columns 1 and 2) and High_UNION (Columns 3 and 4) are consistently positive and statistically significant, suggesting that financial analysts are more likely to issue optimistic forecasts to unionised firms, where uncertainty in human capital is higher and the information environment is poorer. Economically, financial analysts have around a 3 per cent ${ }^{19}$ higher propensity to make optimistic earnings forecasts for firms in highly unionised industries (High_UNION=1), relative to their counterparts in less unionised industries (High_UNION=0). These results are consistent with financial analysts exhibiting strategic behaviour by issuing optimistic forecasts in response to the substantial uncertainty in human capital created by collective-bargaining power.

Collectively, the evidence of strategic optimism and reliance on corporate disclosure of labour costs, along with the lower quality of analysts' forecasts, presents a consistent picture of financial analysts playing a predominantly "complementary role" in the capital markets in the presence of high uncertainty in human capital.

\section{***Insert Table 8 here***}

\section{Conclusion}

In this paper, we examine the primary role of financial analysts in the context of unionised firms, where investors have a greater information demand and a higher reliance on analysts' research. Using a large U.S. panel dataset over a long sample period of 1983-2015, we document evidence consistent with financial analysts primarily playing a "complementary" rather than a "substitutive" role, when firms are subject to heightened uncertainty in human capital. In line with our argument that labour unions affect analysts' forecasting by bringing significant uncertainty into labour costs, we document that the availability of labour cost information significantly mitigates this effect on analysts' earnings forecast quality, in terms of both accuracy and dispersion. Crucially, the mitigating effect of labour cost information also confirms that financial analysts rely more on readily available information disclosed by management than on original information

\footnotetext{
19 The marginal effects for Column 3 and 4 are 0.035 and 0.026 , respectively.
} 
obtained through their own sophisticated research, even though such information can be extremely relevant and valuable for unionised firms.

Our study adds to the ongoing debate on the primary role of financial analysts in the information environment of capital markets (Lang and Lundholm 1996; Altınkilıç et al. 2013; Loh and Stulz 2018; Schantl 2018; Huang et al. 2018; Jennings 2019) by offering new insights into the interplay between financial analysts and an internal stakeholder. In addition, our paper reveals that employees' influence extends beyond the company boundary to a group of sophisticated market participants, i.e., financial analysts, thus potentially affecting the information environment of capital markets. Thirdly, consistent with the argument that accounting information is losing value relevance (Lev 2018), our study suggests that non-financial information on human capital, often neglected or considered secondary to conventional financial information by analysts and investors, is informative and would complement the existing financial reporting system. Lastly, given that such information is highly relevant to investors, regulators and standard setters may also consider making disclosure on human capital mandatory.

This study is subject to some limitations. First, we use the industry-level unionisation rate to proxy for the firm-level unionisation rate. While this ensures consistency with previous union studies (Klasa et al. 2009; Chen et al. 2011; Chino 2016; Huang et al. 2017) and greater generalisability of our results, more recent union papers (Bradley et al. 2017c; Campello et al. 2018) exploit the setting of union elections in the U.S. and apply the quasi-experimental regression discontinuity design to establish the causal impact of unionisation. Second, in this paper, we mainly focus on the properties of analysts' earnings forecasts to infer analysts' primary role, but do not consider other analyst outputs, such as analyst revisions, target prices or stock recommendations. Third, the scope of this paper and hence our main finding is limited to the context of organised labour, and we acknowledge that, in other settings or contexts, analysts may be more motivated to produce new information rather than disseminating and interpreting public information. Given the growing awareness of and necessity for stakeholder management, it is equally important to examine the role of other stakeholders such as suppliers or customers in the information environment, and how financial analysts interact with these other important stakeholders.

Overall, our study sheds light on the primary role of financial analysts by focusing on the interactions between financial analysts and a key stakeholder within businesses, and highlights the value relevance of an important intangible asset, human capital. 


\section{References}

Aboody, D. and Lev, B. (1998). The Value Relevance of Intangibles: The Case of Software Capitalization. Journal of Accounting Research, 36(36), pp.161-191.

Akerlof, G.A. and Yellen, J.L. (1988). Fairness and Unemployment. American Economic Review, 78(2), pp.44-49.

Altınkılıç, O., Balashov, V.S. and Hansen, R.S. (2013). Are Analysts' Forecasts Informative to the General Public? Management Science, 59(11), pp.2550-2565.

Amir, E. and Lev, B. (1996). Value-Relevance of Nonfinancial Information: The Wireless Communications Industry. Journal of Accounting and Economics, 22(1-3), pp.3-30.

Amir, E., Lev, B. and Sougiannis, T. (2003). Do Financial Analysts Get Intangibles? European Accounting Review, 12(4), pp.635-659.

Amiram, D., Landsman, W.R., Owens, E.L. and Stubben, S.R. (2018). How Are Analysts' Forecasts Affected by High Uncertainty? Journal of Business Finance \& Accounting, 45(3-4), pp.295318.

Amiram, D., Owens, E. and Rozenbaum, O. (2016). Do Information Releases Increase or Decrease Information Asymmetry? New Evidence from Analyst Forecast Announcements. Journal of Accounting and Economics, 62(1), pp.121-138.

Armstrong, C.S., Balakrishnan, K. and Cohen, D. (2012). Corporate Governance and the Information Environment: Evidence from State Antitakeover Laws. Journal of Accounting and Economics, 53(1-2), pp.185-204.

Ashenfelter, O. and Johnson, G.E. (1969). Bargaining Theory, Trade Unions, and Industrial Strike Activity. American Economic Review, 59(1), pp.35-49.

Asquith, P., Mikhail, M.B. and Au, A.S. (2005). Information Content of Equity Analyst Reports. Journal of Financial Economics, 75(2), pp.245-282.

Atanassov, J. and Kim, E.H. (2009). Labor and Corporate Governance: International Evidence from Restructuring Decisions. Journal of Finance, 64(1), pp.341-374.

Barron, O.E., Byard, D., Kile, C. and Riedl, E.J. (2002). High-Technology Intangibles and Analysts' Forecasts. Journal of Accounting Research, 40(2), pp.289-312.

Barron, O.E., Byard, D. and Yu, Y. (2008). Earnings Surprises that Motivate Analysts to Reduce Average Forecast Error. The Accounting Review, 83(2), pp.303-325.

Barron, O.E., Byard, D. and Yu, Y. (2017). Earnings Announcement Disclosures and Changes in Analysts' Information. Contemporary Accounting Research, 34(1), pp.343-373.

Barron, O.E. and Stuerke, P.S. (1998). Dispersion in Analysts' Earnings Forecasts as a Measure of Uncertainty. Journal of Accounting, Auditing \& Finance, 13(3), pp.245-270.

Bartov, E., Givoly, D. and Hayn, C. (2002). The Rewards to Meeting or Beating Earnings Expectations. Journal of Accounting and Economics, 33(2), pp.173-204.

Becker, B.E. and Olson, C.A. (1986). The Impact of Strikes on Shareholder Equity. Industrial and Labor Relations Review, 39(3), pp.425-438.

Behn, B.K., Choi, J. and Kang, T. (2008). Audit Quality and Properties of Analyst Earnings Forecasts. The Accounting Review, 83(2), pp.327-349.

Bentley, J.W., Christensen, T.E., Gee, K.H. and Whipple, B.C. (2018). Disentangling Managers' and Analysts' non-GAAP Reporting. Journal of Accounting Research, 56(4), pp.1039-1081. 
Beyer, A., Cohen, D.A., Lys, T.Z. and Walther, B.R. (2010). The Financial Reporting Environment: Review of the Recent Literature. Journal of Accounting and Economics, 50(2-3), pp.296-343.

Bhat, G., Hope, O.K. and Kang, T. (2006). Does Corporate Governance Transparency Affect the Accuracy of Analyst Forecasts? Accounting and Finance, 46(5), pp.715-732.

Bova, F. (2013). Labor Unions and Management's Incentive to Signal a Negative Outlook. Contemporary Accounting Research, 30(1), pp.14-41.

Bradley, D., Gokkaya, S. and Liu, X. (2017a). Before an Analyst Becomes an Analyst: Does Industry Experience Matter? Journal of Finance, 72(2), pp.751-792.

Bradley, D., Gokkaya, S., Liu, X. and Xie, F. (2017b). Are All Analysts Created Equal? Industry Expertise and Monitoring Effectiveness of Financial Analysts. Journal of Accounting and Economics, 63(2-3), pp.179-206.

Bradley, D., Kim, I. and Tian, X. (2017c). Do Unions Affect Innovation? Management Science, 63(7), pp.2251-2271.

Bradshaw, M., Ertimur, Y. and O’Brien, P. (2017). Financial Analysts and Their Contribution to Well-Functioning Capital Markets. Foundations and Trends in Accounting, 11(3), pp.119-191.

Bradshaw, M.T. (2011). Analysts' Forecasts: What do we Know after Decades of Work? SSRN, (June), pp.1-55.

Bronars, S. and Deere, D. (1991). The Threat of Unionization, the Use of Debt, and the Preservation of Shareholder Wealth. Quarterly Journal of Economics, 106(1), pp.231-254.

Byard, D., Li, Y. and Weintrop, J. (2006). Corporate Governance and the Quality of Financial Analysts' Information. Journal of Accounting and Public Policy, 25(5), pp.609-625.

Campello, M., Gao, J., Qiu, J. and Zhang, Y. (2018). Bankruptcy and the Cost of Organized Labor: Evidence from Union Elections. Review of Financial Studies, 31(3), pp.980-1013.

Card, D. (1996). The Effect of Unions on the Structure of Wages: A Longitudinal Analysis. Econometrica, 64(4), pp.957-979.

Card, D. (2001). The Effect of Unions on Wage Inequality in the U.S. Labor Market. Industrial and Labor Relations Review, 54(2), pp.296-315.

Chan, L.K.C., Karceski, J. and Lakonishok, J. (2007). Analysts' Conflicts of Interest and Biases in Earnings Forecasts. Journal of Financial and Quantitative Analysis, 42(04), p.893.

Chang, X., Dasgupta, S. and Hilary, G. (2006). Analyst Coverage and Financing Decisions. Journal of Finance, 61(6), pp.3009-3048.

Chen, H., Kacperczyk, M. and Ortiz-Molina, H. (2012). Do Nonfinancial Stakeholders Affect the Pricing of Risky Debt? Evidence from Unionized Workers. Review of Finance, 16(2), pp.347383.

Chen, H.J., Kacperczyk, M. and Ortiz-Molina, H. (2011). Labor Unions, Operating Flexibility, and the Cost of Equity. Journal of Financial and Quantitative Analysis, 46(01), pp.25-58.

Chen, N.X., Chiu, P.-C. and Shevlin, T. (2018). Do Analysts Matter for Corporate Tax Planning? Evidence from a Natural Experiment. Contemporary Accounting Research, 35(2), pp.794-829.

Chen, T., Harford, J. and Lin, C. (2015). Do Analysts Matter for Governance? Evidence from Natural Experiments. Journal of Financial Economics, 115(2), pp.383-410.

Chen, T. and Lin, C. (2017). Does Information Asymmetry Affect Corporate Tax Aggressiveness? Journal of Financial and Quantitative Analysis, 52(5), pp.2053-2081. 
Chen, T., Xie, L. and Zhang, Y. (2017). How Does Analysts' Forecast Quality Relate to Corporate Investment Efficiency? Journal of Corporate Finance, 43, pp.217-240.

Chen, X., Cheng, Q. and Lo, K. (2010). On the Relationship between Analyst Reports and Corporate Disclosures: Exploring the Roles of Information Discovery and Interpretation. Journal of Accounting and Economics, 49(3), pp.206-226.

Cheng, L. (2017). Organized Labor and Debt Contracting: Firm-Level Evidence from Collective Bargaining. Accounting Review, 92(3), pp.57-85.

Chino, A. (2016). Do Labor Unions Affect Firm Payout Policy? Operating Leverage and Rent Extraction Effects. Journal of Corporate Finance, 41, pp.156-178.

Chung, R., Lee, B.B.-H., Lee, W.-J. and Sohn, B.C. (2016). Do Managers Withhold Good News from Labor Unions? Management Science, 62(1), pp.46-68.

Chyz, J.A., Ching Leung, W.S., Zhen Li, O. and Meng Rui, O. (2013). Labor Unions and Tax Aggressiveness. Journal of Financial Economics, 108(3), pp.675-698.

Clark, K.B. (1984). Unionization and Firm Performance: The Impact on Profits, Growth, and Productivity. American Economic Review, 74(5), pp.893-919.

Clement, M.B. (1999). Analyst Forecast Accuracy: Do Ability, Resources, and Portfolio Complexity Matter? Journal of Accounting and Economics, 27(3), pp.285-303.

Clement, M.B. and Tse, S. (2005). Financial Analyst Characteristics and Herding Behavior in Forecasting. Journal of Finance, 60(1), pp.307-341.

Cohen, D.A., Dey, A. and Lys, T.Z. (2008). Real and Accrual-Based Earnings Management in the Pre- and Post-Sarbanes-Oxley Periods. Accounting Review, 83(3), pp.757-787.

Connolly, R.A., Hirsch, B.T. and Hirschey, M. (1986). Union Rent Seeking, Intangible Capital, and Market Value of the Firm. The Review of Economics and Statistics, 68(4), pp.567-577.

Cotter, J., Tuna, I. and Wysocki, P.D. (2006). Expectations Management and Beatable Targets: How do Analysts React to Explicit Earnings Guidance? Contemporary Accounting Research, 23(3), pp.593-628.

Cramton, P. and Tracy, J.S. (1992). Strikes and Holdouts in Wage Bargaining: Theory and Data. The American Economic Review, 82(1), pp.100-121.

Das, S., Levine, C.B. and Sivaramakrishnan, K. (1998). Earnings Predictability and Bias in Analysts' Earnings Forecasts. Accounting Review, 73(2), pp.277-294.

DeAngelo, H. and DeAngelo, L. (1991). Union Negotiations and Corporate Policy. A Study of Labor Concessions in the Domestic Steel Industry During the 1980s. Journal of Financial Economics, 30(1), pp.3-43.

Dechow, P., Ge, W. and Schrand, C. (2010). Understanding Earnings Quality: A Review of the Proxies, Their Determinants and Their Consequences. Journal of Accounting and Economics, 50(2-3), pp.344-401.

De Franco, G., Kothari, S.P. and Verdi, R.S. (2011). The Benefits of Financial Statement Comparability. Journal of Accounting Research, 49(4), pp.895-931.

Dhaliwal, D.S., Radhakrishnan, S., Tsang, A. and Yang, Y.G. (2012). Nonfinancial Disclosure and Analyst Forecast Accuracy: International Evidence on Corporate Social Responsibility Disclosure. Accounting Review, 87(3), pp.723-759.

Diether, K., Malloy, C.J. and Scherbina, A. (2002). Differences of Opinion and the Cross-Section of Stock Returns. Journal of Finance, 57(5), pp.2113-2141. 
DiNardo, J. and Lee, D. (2004). Economic Impacts of new Unionization on Private Sector Employers: 1984-2001. Quarterly Journal of Economics, 119(4), pp.1383-1441.

Duru, A. and Reeb, D.M. (2002). International Diversification and Analysts' Forecast and Bias. The Accounting Review, 77(2), pp.415-433.

Ellwood, D.T. and Fine, G. (1987). The Impact of Right-to-Work Laws on Union Organizing. Journal of Political Economy, 95(2), pp.250-273.

Faleye, O., Mehrotra, V. and Morck, R. (2006). When Labor Has a Voice in Corporate Governance. Journal of Financial and Quantitative Analysis, 41(03), p.489.

Farber, H.S. and Saks, D.H. (1980). Why Workers Want Unions: The Role of Relative Wages and Job Characteristics. Journal of Political Economy, 88(2), pp.349-369.

Francis, J. and Schipper, K. (1999). Have Financial Statements Lost Their Relevance? Journal of Accounting Research, 37(2), p.319.

Freeman, R. (1980). Unionism and the Dispersion of Wages. Industrial and Labor Relations Review, 34(1), pp.3-23.

Freeman, R. (1981). The Effect of Unionism on Fringe Benefits. Industrial and Labor Relations Review, 34(4), p.489.

Freeman, R. and Medoff, J. (1979). Two Faces of Unionism. Public Interest, 57, pp.69-93.

Freeman, R. and Medoff, J. (1984). What do Unions do? New York: Basic Books.

Ghaly, M., Dang, V.A. and Stathopoulos, K. (2017). Cash Holdings and Labor Heterogeneity: The Role of Skilled Labor. The Review of Financial Studies, 30(10), pp.3636-3668.

Gu, W. and Kuhn, P. (1998). A Theory of Holdouts in Wage Bargaining. The American Economic Review, 88(3), pp.428-449.

Hamm, S.J.W., Jung, B. and Lee, W.-J. (2018). Labor Unions and Income Smoothing. Contemporary Accounting Research, 35(3), pp.1201-1228.

Hashim, N.A. and Strong, N.C. (2018). Do Analysts' Cash Flow Forecasts Improve Their Target Price Accuracy? Contemporary Accounting Research, 35(4), pp.1816-1842.

He, J. and Tian, X. (2013). The Dark Side of Analyst Coverage: The Case of Innovation. Journal of Financial Economics, 109(3), pp.856-878.

Healy, P.M. and Palepu, K.G. (2001). Information Asymmetry, Corporate Disclosure, and the Capital Markets: A Review of the Empirical Disclosure Literature. Journal of Accounting and Economics, 31(1-3), pp.405-440.

Hilary, G. (2006). Organized Labor and Information Asymmetry in the Financial Markets. Review of Accounting Studies, 11(4), pp.525-548.

Hirsch, B.T. and Macpherson, D.A. (2003). Union Membership and Coverage Database from the Current Population Survey (CPS): Note. Industrial and Labor Relations Review, 56(2), pp.349354.

Hong, H. and Kubik, J.D. (2003). Analyzing the Analysts: Career Concerns and Biased Earnings Forecasts. Journal of Finance, 58(1), pp.313-351.

Hong, H., Kubik, J.D. and Solomon, A. (2000). Security Analysts' Career Concerns and Herding of Earnings Forecasts. The RAND Journal of Economics, 31(1), pp.121-144.

Hope, O.-K. (2003a). Disclosure Practices, Enforcement of Accounting Standards, and Analysts' Forecast Accuracy: An International Study. Journal of Accounting Research, 41(2), pp.235-272. 
Hope, O.-K. (2003b). Accounting Policy Disclosure and Analysts' Forecasts. Contemporary Accounting Research, 20(2), pp.295-321.

Horton, J., Serafeim, G. and Serafeim, I. (2013). Does Mandatory IFRS Adoption Improve the Information Environment? Contemporary Accounting Research, 30(1), pp.388-423.

Horton, J., Serafeim, G. and Wu, S. (2017). Career Concerns of Banking Analysts. Journal of Accounting and Economics, 63(2-3), pp.231-252.

Huang, A.H., Lehavy, R., Zang, A.Y. and Zheng, R. (2018). Analyst Information Discovery and Interpretation Roles: A Topic Modeling Approach. Management Science, 64(6), pp.2833-2855.

Huang, Q., Jiang, F., Lie, E. and Que, T. (2017). The Effect of Labor Unions on CEO Compensation. Journal of Financial and Quantitative Analysis, 52(2), pp.553-582.

Imhoff, E.A. and Lobo, G.J. (1992). The Effect of Ex Ante Earnings Uncertainty on Earnings Response Coefficients. The Accounting Review, 67(2), pp.427-439.

Irani, R.M. and Oesch, D. (2013). Monitoring and Corporate Disclosure: Evidence from a Natural Experiment. Journal of Financial Economics, 109(2), pp.398-418.

Jennings, J. (2019). The Role of Sell-Side Analysts after Accusations of Managerial Misconduct. The Accounting Review, 94(1), pp.183-203.

John, K., Knyazeva, A. and Knyazeva, D. (2015). Employee Rights and Acquisitions. Journal of Financial Economics, 118(1), pp.49-69.

Kim, J.B., Li, L., Lu, L.Y. and Yu, Y. (2016). Financial Statement Comparability and Expected Crash Risk. Journal of Accounting and Economics, 61(2-3), pp.294-312.

Klasa, S., Maxwell, W.F. and Ortiz-Molina, H. (2009). The Strategic Use of Corporate Cash Holdings in Collective Bargaining with Labor Unions. Journal of Financial Economics, 92(3), pp.421-442.

Kothari, S.P., Leone, A.J. and Wasley, C.E. (2005). Performance Matched Discretionary Accrual Measures. Journal of Accounting and Economics, 39(1), pp.163-197.

Kross, W., Ro, B. and Schroeder, D. (1990). Earnings Expectations: The Analysts' Information Advantage. The Accounting Review, 65(2), pp.461-476.

Lang, M.H., Lins, K.V. and Miller, D.P. (2003). ADRs, Analysts, and Accuracy: Does Cross Listing in the United States Improve a Firm's Information Environment and Increase Market Value? Journal of Accounting Research, 41(2), pp.317-345.

Lang, M.H. and Lundholm, R.J. (1996). Corporate Disclosure Policy and Analyst Behavior. Accounting Review, 71(4), pp.467-492.

Lee, D.S. and Mas, A. (2012). Long-Run Impacts of Unions on Firms: New Evidence from Financial Markets, 1961-1999. Quarterly Journal of Economics, 127(1), pp.333-378.

Lev, B. (2018). The Deteriorating Usefulness of Financial Report Information and how to Reverse it. Accounting and Business Research, 48(5), pp.465-493.

Lewis, H.G. (1964). Relative Employment Effects of Unionism. The American Economic Review, 54(3), pp.123-132.

Lewis, H.G. (1986). Union Relative Wage Effects: A Survey. Chicago: University of Chicago Press.

Liberty, S.E. and Zimmerman, J.L. (1986). Labor Union Contract Negotiations and Accounting Choices. The Accounting Review, 61(4), pp.692-712.

Lim, T. (2001). Rationality and Analysts' Forecasts Bias. Journal of Finance, 56(1), pp.369-385. 
Lin, C., Schmid, T. and Xuan, Y. (2018). Employee Representation and Financial Leverage. Journal of Financial Economics, 127(2), pp.303-324.

Livnat, J. and Zhang, Y. (2012). Information Interpretation or Information Discovery: Which Role of Analysts do Investors Value More? Review of Accounting Studies, 17(3), pp.612-641.

Loh, R.K. and Stulz, R.M. (2018). Is Sell-Side Research More Valuable in Bad Times? Journal of Finance, 73(3), pp.959-1013.

Mansi, S.A., Maxwell, W.F. and Miller, D.P. (2011). Analyst Forecast Characteristics and the Cost of Debt. Review of Accounting Studies, 16(1), pp.116-142.

Matsa, D.A. (2010). Capital Structure as a Strategic Variable: Evidence from Collective Bargaining. Journal of Finance, 65(3), pp.1197-1232.

Mattei, M.M. and Platikanova, P. (2017). Do Product Market Threats Affect Analyst Forecast Precision? Review of Accounting Studies, 22(4), pp.1628-1665.

Mayew, W.J. (2008). Evidence of Management Discrimination among Analysts during Earnings Conference Calls. Journal of Accounting Research, 46(3), pp.627-659.

Merkley, K., Michaely, R. and Pacelli, J. (2017a). Cultural Diversity on Wall Street: Evidence from Sell-Side Analysts' Forecasts. SSRN Electronic Journal (July).

Merkley, K., Michaely, R. and Pacelli, J. (2017b). Does the Scope of the Sell-Side Analyst Industry Matter? An Examination of Bias, Accuracy, and Information Content of Analyst Reports. Journal of Finance, 72(3), pp.1285-1334.

Michaely, R. and Womack, K.L. (1999). Conflict of Interest and the Credibility of Underwriter Analyst Recommendations. Review of Financial Studies, 12(4), pp.653-686.

Mikhail, M.B., Walther, B.R. and Willis, R.H. (1999). Does Forecast Accuracy Matter to Security Analysts? The Accounting Review, 74(2), pp.185-200.

Myers, B.W. and Saretto, A. (2016). Does Capital Structure Affect the Behavior of Nonfinancial Stakeholders? An Empirical Investigation into Leverage and Union Strikes. Management Science, 62(11), pp.3235-3253.

Pencavel, J. and Hartsog, C.E. (1984). A Reconsideration of the Effects of Unionism on Relative Wages and Employment in the United States, 1920-1980. Journal of Labor Economics, 2(2), pp.193232.

Petaibanlue, J., Walker, M. and Lee, E. (2015). When Did Analyst Forecast Accuracy Benefit from Increased Cross-Border Comparability Following IFRS Adoption in the EU? International Review of Financial Analysis, 42, pp.278-291.

Petersen, M.A. (2009). Estimating Standard Errors in Finance Panel Data Sets: Comparing Approaches. Review of Financial Studies, 22(1), pp.435-480.

Reder, M.W. and Neumann, G.R. (1980). Conflict and Contract: The Case of Strikes. Journal of Political Economy, 88(5), pp.867-886.

Reuters. (2008). Boeing Set to Announce New 787 Delays. New York. Available at: https://www.reuters.com/article/us-boeing-idUSTRE4B384G20081204 [Acessed: 1 August, 2018]

Reuters. (2016). Verizon, Unions Agree to Pay Raises, New Jobs to End Strike. Available at: https://www.reuters.com/article/us-verizon-strike-deal/verizon-unions-agree-to-pay-raisesnew-jobs-to-end-strike-idUSKCN0YL1E7 [Acessed: 1 August, 2018]

Roychowdhury, S. (2006). Earnings Management through Real Activities Manipulation. Journal of 
Accounting and Economics, 42(3), pp.335-370.

Ruback, R.S. and Zimmerman, M.B. (1984). Unionization and Profitability: Evidence from the Capital Market. Journal of Political Economy, 92(6), p.1134.

Schantl, S.F. (2018). Analyst Information Acquisition and the Relative Informativeness of Analyst Forecasts and Managed Earnings. Accounting and Business Research, 48(1), pp.62-76.

Schmidt, M.B. and Berri, D.J. (2004). The Impact of Labor Strikes on Consumer Demand: An Application to Professional Sports. American Economic Review, 94(1), pp.344-357.

Soltes, E. (2014). Private Interaction between Firm Management and Sell-Side Analysts. Journal of Accounting Research, 52(1), pp.245-272.

Tan, H., Wang, S. and Welker, M. (2011). Analyst Following and Forecast Accuracy after Mandated IFRS Adoptions. Journal of Accounting Research, 49(5), pp.1307-1357.

To, T.Y., Navone, M. and Wu, E. (2018). Analyst Coverage and the Quality of Corporate Investment Decisions. Journal of Corporate Finance, 51(June), pp.164-181.

Tracy, J.S. (1986). An Investigation into the Determinants of U.S. Strike Activity. The American Economic Review, 76(3), pp.423-436.

Wall Street Journal. (2016). Verizon CEO: Strike May Hit Results. Available at: https://www.wsi.com/articles/verizon-ceo-strike-may-hit-results-1464101544 [Acessed: 1 August, 2018]

Wooldridge, J.M. (2010). Econometric Analysis of Cross Section and Panel Data. Second Ed. MIT Press, Cambridge, Massachusetts.

Yu, F. (2008). Analyst Coverage and Earnings Management. Journal of Financial Economics, 88(2), pp.245-271.

Zhang, X.F. (2006a). Information Uncertainty and Analyst Forecast Behavior. Contemporary Accounting Research, 23(2), pp.565-590.

Zhang, X.F. (2006b). Information Uncertainty and Stock Returns. Journal of Finance, 61(1), pp.105-137. 


\section{Table 1: Descriptive Statistics}

This table presents the descriptive statistics for variables used in our baseline analysis. Variables are defined in the appendix.

\begin{tabular}{lcccccc}
\hline Variable & Mean & $\boldsymbol{p} 25$ & Median & $\boldsymbol{p 7 5}$ & $\boldsymbol{S D}$ & $\boldsymbol{N}$ \\
\hline UNION & 0.096 & 0.019 & 0.048 & 0.138 & 0.113 & 93530 \\
ANALYST_NUM & 29.882 & 7.000 & 18.000 & 39.000 & 34.170 & 93530 \\
FERROR & 0.052 & 0.002 & 0.007 & 0.023 & 0.222 & 92259 \\
FDISPER & 0.031 & 0.002 & 0.006 & 0.018 & 0.115 & 92003 \\
SIZE & 6.278 & 4.905 & 6.123 & 7.483 & 1.899 & 93387 \\
MTB & 3.951 & 1.215 & 1.906 & 3.207 & 160.473 & 93339 \\
LOSS & 0.242 & 0.000 & 0.000 & 0.000 & 0.428 & 93530 \\
EARNSURP & 1.158 & 0.027 & 0.226 & 0.659 & 72.344 & 88746 \\
LEV & 0.222 & 0.039 & 0.179 & 0.341 & 0.219 & 92845 \\
RD_EXP & 0.044 & 0.000 & 0.000 & 0.043 & 0.115 & 93530 \\
AGE & 2.224 & 1.609 & 2.398 & 2.996 & 0.985 & 93530 \\
ZSCORE & 6.172 & 2.139 & 3.562 & 5.946 & 102.764 & 72734 \\
SD_INCOME & 0.062 & 0.011 & 0.026 & 0.061 & 0.179 & 70491 \\
SD_STK & 0.031 & 0.019 & 0.027 & 0.038 & 0.017 & 93511 \\
\hline \hline
\end{tabular}




\section{Table 2: Labour Unionisation Rate and Analysts' Forecast Accuracy}

This table reports the results for the effect of labour unions on analysts' forecast accuracy. The dependent variable is forecast error (FERROR). The variable of interest is the unionisation rate in the firm's CIC industry (UNION). P-values are displayed in parentheses, with standard errors clustered at the CIC industry level, in Columns 1-3. For robustness, standard errors are clustered at both the industry and the year level in Columns $4-6 . * * *, * *$ and $*$ indicate significance at 1\%, 5\% and $10 \%$, respectively. All variables are defined in the appendix.

\begin{tabular}{|c|c|c|c|c|c|c|}
\hline & \multicolumn{6}{|c|}{ Pooled OLS } \\
\hline & (1) & (2) & (3) & (4) & (5) & (6) \\
\hline & FERROR & FERROR & FERROR & FERROR & FERROR & FERROR \\
\hline \multirow[t]{2}{*}{ UNION } & $0.043^{* *}$ & $0.046^{*}$ & $0.059 * *$ & $0.043^{* * *}$ & $0.046^{* *}$ & $0.059 * *$ \\
\hline & $(0.037)$ & (0.091) & $(0.046)$ & $(0.006)$ & $(0.035)$ & $(0.015)$ \\
\hline \multirow[t]{2}{*}{ SIZE } & $-0.035^{* * *}$ & $-0.036^{* * *}$ & $-0.034^{* * *}$ & $-0.035^{* * *}$ & $-0.036^{* * *}$ & $-0.034^{* * *}$ \\
\hline & $(0.000)$ & $(0.000)$ & $(0.000)$ & $(0.000)$ & $(0.000)$ & $(0.000)$ \\
\hline \multirow[t]{2}{*}{ MTB } & 0.000 & 0.000 & 0.000 & 0.000 & 0.000 & 0.000 \\
\hline & $(0.365)$ & $(0.681)$ & $(0.897)$ & $(0.255)$ & $(0.646)$ & $(0.887)$ \\
\hline \multirow[t]{2}{*}{ LOSS } & $0.051 * * *$ & $0.049 * * *$ & $0.047 * * *$ & $0.051 * * *$ & $0.049 * * *$ & $0.047 * * *$ \\
\hline & $(0.000)$ & $(0.000)$ & $(0.000)$ & $(0.000)$ & $(0.000)$ & $(0.000)$ \\
\hline \multirow[t]{2}{*}{ EARNSURP } & 0.000 & 0.000 & 0.000 & 0.000 & 0.000 & 0.000 \\
\hline & $(0.314)$ & $(0.395)$ & $(0.469)$ & $(0.287)$ & $(0.357)$ & $(0.440)$ \\
\hline \multirow[t]{2}{*}{ LEV } & $0.068^{* * *}$ & $0.069 * * *$ & $0.071 * * *$ & $0.068^{* * *}$ & $0.069^{* * *}$ & $0.071 * * *$ \\
\hline & $(0.000)$ & $(0.000)$ & $(0.000)$ & $(0.000)$ & $(0.000)$ & $(0.000)$ \\
\hline \multirow[t]{2}{*}{$R D \_E X P$} & 0.079 & 0.079 & $0.090^{*}$ & 0.079 & 0.079 & $0.090^{*}$ \\
\hline & $(0.128)$ & $(0.143)$ & $(0.096)$ & $(0.131)$ & (0.138) & $(0.095)$ \\
\hline \multirow[t]{2}{*}{$A G E$} & $0.019 * * *$ & $0.018^{* * *}$ & $0.019^{* * *}$ & $0.019 * * *$ & $0.018^{* * *}$ & $0.019 * * *$ \\
\hline & $(0.000)$ & $(0.000)$ & $(0.000)$ & $(0.000)$ & $(0.000)$ & $(0.000)$ \\
\hline \multirow[t]{2}{*}{ ZSCORE } & $0.000^{* * *}$ & $0.000^{* * *}$ & $0.000^{* *}$ & $0.000^{* * *}$ & $0.000^{* * *}$ & $0.000^{* *}$ \\
\hline & $(0.000)$ & $(0.000)$ & $(0.021)$ & $(0.000)$ & $(0.000)$ & $(0.031)$ \\
\hline \multirow[t]{2}{*}{ SD_INCOME } & $0.052^{*}$ & $0.052^{*}$ & $0.061^{* *}$ & $0.052^{*}$ & $0.052^{*}$ & $0.061 *$ \\
\hline & $(0.050)$ & $(0.067)$ & $(0.043)$ & $(0.070)$ & $(0.086)$ & $(0.057)$ \\
\hline \multirow[t]{2}{*}{ SD_STK } & $2.040^{* * *}$ & $2.110^{* * *}$ & $2.146^{* * *}$ & $2.040 * * *$ & $2.110^{* * *}$ & $2.146^{* * *}$ \\
\hline & $(0.000)$ & $(0.000)$ & $(0.000)$ & $(0.000)$ & $(0.000)$ & $(0.000)$ \\
\hline \multirow[t]{2}{*}{ ANALYST_NUM } & $0.001 * * *$ & $0.001 * * *$ & $0.001 * * *$ & $0.001 * * *$ & $0.001 * * *$ & $0.001 * * *$ \\
\hline & $(0.000)$ & $(0.000)$ & $(0.000)$ & $(0.000)$ & $(0.000)$ & $(0.000)$ \\
\hline Firm FE & $\mathrm{Y}$ & $\mathrm{Y}$ & $\mathrm{Y}$ & $\mathrm{Y}$ & $\mathrm{Y}$ & $\mathrm{Y}$ \\
\hline Year FE & $\mathrm{Y}$ & $\mathrm{N}$ & $\mathrm{N}$ & $\mathrm{Y}$ & $\mathrm{N}$ & $\mathrm{N}$ \\
\hline Industry $\times$ Year FE & $\mathrm{N}$ & $\mathrm{Y}$ & $\mathrm{Y}$ & $\mathrm{N}$ & $\mathrm{Y}$ & $\mathrm{Y}$ \\
\hline State FE & $\mathrm{N}$ & $\mathrm{N}$ & $\mathrm{Y}$ & $\mathrm{N}$ & $\mathrm{N}$ & $\mathrm{Y}$ \\
\hline Clustered by industry & $\mathrm{Y}$ & $\mathrm{Y}$ & $\mathrm{Y}$ & $\mathrm{Y}$ & $\mathrm{Y}$ & $\mathrm{Y}$ \\
\hline Clustered by year & $\mathrm{N}$ & $\mathrm{N}$ & $\mathrm{N}$ & $\mathrm{Y}$ & $\mathrm{Y}$ & $\mathrm{Y}$ \\
\hline $\mathrm{R}^{2}$ & 0.521 & 0.541 & 0.540 & 0.521 & 0.541 & 0.540 \\
\hline $\mathrm{N}$ & 52634 & 52460 & 48388 & 52634 & 52460 & 48388 \\
\hline
\end{tabular}




\section{Table 3: Labour Unionisation Rate and Analysts' Forecast Dispersion}

This table reports the results for the effect of labour unions on analysts' forecast accuracy. The dependent variable is forecast dispersion (FDISPER). The variable of interest is the unionisation rate in the firm's CIC industry (UNION). P-values are displayed in parentheses with standard errors clustered at the CIC industry level in Columns 1-3. For robustness, standard errors are clustered at both the industry and year levels in Columns 4-6.***,** and * indicate significance at $1 \%, 5 \%$ and $10 \%$, respectively. All variables are defined in the appendix.

\begin{tabular}{|c|c|c|c|c|c|c|}
\hline & \multicolumn{6}{|c|}{ Pooled OLS } \\
\hline & (1) & (2) & (3) & (4) & (5) & (6) \\
\hline & FDISPER & FDISPER & FDISPER & FDISPER & FDISPER & FDISPER \\
\hline \multirow[t]{2}{*}{ UNION } & 0.017 & $0.031^{* *}$ & $0.035^{* *}$ & 0.017 & $0.031^{* *}$ & $0.035^{* *}$ \\
\hline & (0.143) & $(0.030)$ & $(0.026)$ & (0.131) & $(0.021)$ & (0.018) \\
\hline \multirow[t]{2}{*}{ SIZE } & $-0.022 * * *$ & $-0.022 * * *$ & $-0.022 * * *$ & $-0.022 * * *$ & $-0.022 * * *$ & $-0.022^{* * *}$ \\
\hline & $(0.000)$ & $(0.000)$ & $(0.000)$ & $(0.000)$ & $(0.000)$ & $(0.000)$ \\
\hline \multirow[t]{2}{*}{ MTB } & -0.000 & -0.000 & -0.000 & -0.000 & -0.000 & -0.000 \\
\hline & $(0.923)$ & $(0.250)$ & $(0.174)$ & $(0.916)$ & $(0.220)$ & $(0.165)$ \\
\hline \multirow[t]{2}{*}{ LOSS } & $0.024 * * *$ & $0.023^{* * *}$ & $0.023 * * *$ & $0.024 * * *$ & $0.023 * * *$ & $0.023^{* * *}$ \\
\hline & $(0.000)$ & $(0.000)$ & $(0.000)$ & $(0.000)$ & $(0.000)$ & $(0.000)$ \\
\hline \multirow[t]{2}{*}{ EARNSURP } & 0.000 & 0.000 & 0.000 & 0.000 & 0.000 & 0.000 \\
\hline & $(0.668)$ & $(0.765)$ & $(0.955)$ & $(0.649)$ & $(0.744)$ & (0.954) \\
\hline \multirow[t]{2}{*}{ LEV } & $0.027^{* * *}$ & $0.027 * * *$ & $0.029 * * *$ & $0.027 * * *$ & $0.027 * * *$ & $0.029 * * *$ \\
\hline & $(0.000)$ & $(0.000)$ & $(0.000)$ & $(0.000)$ & $(0.000)$ & $(0.000)$ \\
\hline \multirow[t]{2}{*}{$R D \_E X P$} & 0.018 & 0.017 & $0.021 *$ & $0.018^{* *}$ & $0.017^{* *}$ & $0.021^{* *}$ \\
\hline & $(0.115)$ & $(0.141)$ & $(0.092)$ & $(0.025)$ & $(0.040)$ & $(0.038)$ \\
\hline \multirow[t]{2}{*}{$A G E$} & $0.010^{* * *}$ & $0.010^{* * *}$ & $0.010^{* * *}$ & $0.010^{* * *}$ & $0.010^{* * *}$ & $0.010^{* * *}$ \\
\hline & $(0.000)$ & $(0.000)$ & $(0.000)$ & $(0.001)$ & $(0.001)$ & $(0.000)$ \\
\hline \multirow[t]{2}{*}{ ZSCORE } & 0.000 & -0.000 & $0.000^{* *}$ & 0.000 & -0.000 & $0.000^{*}$ \\
\hline & $(0.794)$ & $(0.870)$ & $(0.037)$ & $(0.801)$ & $(0.889)$ & $(0.055)$ \\
\hline \multirow[t]{2}{*}{ SD_INCOME } & 0.018 & 0.019 & 0.025 & 0.018 & 0.019 & 0.025 \\
\hline & $(0.394)$ & $(0.394)$ & $(0.242)$ & $(0.403)$ & $(0.396)$ & $(0.240)$ \\
\hline \multirow[t]{2}{*}{ SD_STK } & $1.025^{* * *}$ & $1.050^{* * *}$ & $1.060^{* * *}$ & $1.025^{* * *}$ & $1.050^{* * *}$ & $1.060^{* * *}$ \\
\hline & $(0.000)$ & $(0.000)$ & $(0.000)$ & $(0.000)$ & $(0.000)$ & $(0.000)$ \\
\hline \multirow[t]{2}{*}{ ANALYST_NUM } & $0.000^{* * *}$ & $0.000^{* * *}$ & $0.000^{* * *}$ & $0.000^{* * *}$ & $0.000 * * *$ & $0.000^{* * *}$ \\
\hline & $(0.000)$ & $(0.000)$ & $(0.000)$ & $(0.000)$ & $(0.000)$ & $(0.000)$ \\
\hline Firm FE & $\mathrm{Y}$ & $\mathrm{Y}$ & $\mathrm{Y}$ & $\mathrm{Y}$ & $\mathrm{Y}$ & $\mathrm{Y}$ \\
\hline Year FE & $\mathrm{Y}$ & $\mathrm{N}$ & $\mathrm{N}$ & $\mathrm{Y}$ & $\mathrm{N}$ & $\mathrm{N}$ \\
\hline Industry $\times$ Year FE & $\mathrm{N}$ & $\mathrm{Y}$ & $\mathrm{Y}$ & $\mathrm{N}$ & $\mathrm{Y}$ & $\mathrm{Y}$ \\
\hline State FE & $\mathrm{N}$ & $\mathrm{N}$ & $\mathrm{Y}$ & $\mathrm{N}$ & $\mathrm{N}$ & $\mathrm{Y}$ \\
\hline Clustered by industry & $\mathrm{Y}$ & $\mathrm{Y}$ & $\mathrm{Y}$ & $\mathrm{Y}$ & $\mathrm{Y}$ & $\mathrm{Y}$ \\
\hline Clustered by year & $\mathrm{N}$ & $\mathrm{N}$ & $\mathrm{N}$ & $\mathrm{Y}$ & $\mathrm{Y}$ & $\mathrm{Y}$ \\
\hline $\mathrm{R}^{2}$ & 0.576 & 0.592 & 0.590 & 0.576 & 0.592 & 0.590 \\
\hline $\mathrm{N}$ & 52573 & 52392 & 48336 & 52573 & 52392 & 48336 \\
\hline
\end{tabular}




\section{Table 4: Controlling for Financial Reporting Quality}

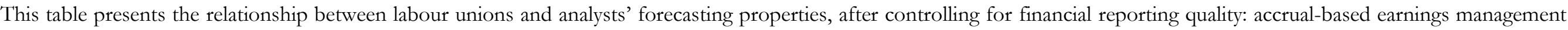

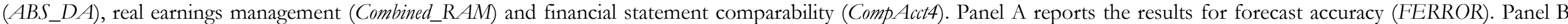

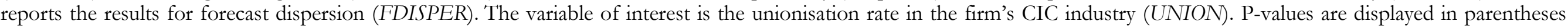

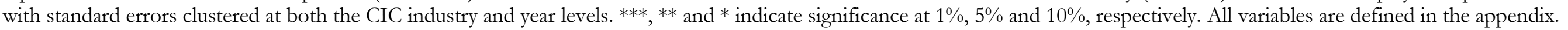

\section{Panel A: Analysts' Forecast Accuracy}

\begin{tabular}{|c|c|c|c|c|c|c|c|c|c|c|c|c|}
\hline & \multicolumn{3}{|c|}{$\begin{array}{c}\text { Accrual-Based } \\
\text { Earnings Management (EM) }\end{array}$} & \multicolumn{3}{|c|}{$\begin{array}{c}\text { Real Activities Manipulation } \\
\text { (RAM) }\end{array}$} & \multicolumn{3}{|c|}{$\begin{array}{c}\text { Financial Statement } \\
\text { Comparability } \\
\text { (FSC) } \\
\end{array}$} & \multicolumn{3}{|c|}{$E M+R A M+F S C$} \\
\hline & FERROR & FERROR & FERROR & FERROR & FERROR & FERROR & FERROR & FERROR & FERROR & FERROR & FERROR & FERROR \\
\hline \multirow[t]{2}{*}{ UNION } & $0.058^{* * *}$ & $0.039 *$ & $0.046^{* *}$ & $0.067 * * *$ & $0.040^{* *}$ & $0.047 * *$ & $0.071 * * *$ & $0.045^{* *}$ & $0.053 * * *$ & $0.064 * * *$ & $0.039 * *$ & $0.047 * *$ \\
\hline & $(0.006)$ & $(0.053)$ & $(0.027)$ & $(0.002)$ & $(0.042)$ & $(0.020)$ & $(0.001)$ & $(0.021)$ & $(0.009)$ & $(0.003)$ & $(0.039)$ & $(0.015)$ \\
\hline$A B S \_D A$ & $(0.001)$ & $(0.001)$ & $(0.001)$ & & & & & & & $(0.001)$ & $(0.001)$ & $(0.001)$ \\
\hline \multirow{2}{*}{ Combined_RAM } & & & & $0.015^{* * *}$ & $0.018^{* * *}$ & $0.018^{* * *}$ & & & & $0.018^{* * *}$ & $0.023 * * *$ & $0.023 * * *$ \\
\hline & & & & $(0.001)$ & $(0.003)$ & $(0.006)$ & & & & $(0.000)$ & $(0.001)$ & $(0.003)$ \\
\hline \multirow{2}{*}{ CompAcct4 } & & & & & & & $-0.012^{* * *}$ & $-0.012 * * *$ & $-0.016^{* * *}$ & $-0.011 * * *$ & $-0.011 * * *$ & $-0.016 * * *$ \\
\hline & & & & & & & $(0.001)$ & $(0.001)$ & $(0.000)$ & $(0.001)$ & $(0.001)$ & $(0.001)$ \\
\hline Other controls & $\mathrm{Y}$ & $\mathrm{Y}$ & $\mathrm{Y}$ & $\mathrm{Y}$ & $\mathrm{Y}$ & $\mathrm{Y}$ & $\mathrm{Y}$ & $\mathrm{Y}$ & $\mathrm{Y}$ & $\mathrm{Y}$ & $\mathrm{Y}$ & $\mathrm{Y}$ \\
\hline Firm FE & $\mathrm{Y}$ & $\mathrm{Y}$ & $\mathrm{Y}$ & $\mathrm{Y}$ & $\mathrm{Y}$ & $\mathrm{Y}$ & $\mathrm{Y}$ & $\mathrm{Y}$ & $\mathrm{Y}$ & $\mathrm{Y}$ & $\mathrm{Y}$ & $\mathrm{Y}$ \\
\hline Industry $\times$ Year FE & $\mathrm{N}$ & $\mathrm{Y}$ & $\mathrm{Y}$ & $\mathrm{N}$ & $\mathrm{Y}$ & $\mathrm{Y}$ & $\mathrm{N}$ & $\mathrm{Y}$ & $\mathrm{Y}$ & $\mathrm{N}$ & $\mathrm{Y}$ & $\mathrm{Y}$ \\
\hline State FE & $\mathrm{N}$ & $\mathrm{N}$ & $\mathrm{Y}$ & $\mathrm{N}$ & $\mathrm{N}$ & $\mathrm{Y}$ & $\mathrm{N}$ & $\mathrm{N}$ & $\mathrm{Y}$ & $\mathrm{N}$ & $\mathrm{N}$ & $\mathrm{Y}$ \\
\hline Clustered by ind. & $\mathrm{Y}$ & $\mathrm{Y}$ & $\mathrm{Y}$ & $\mathrm{Y}$ & $\mathrm{Y}$ & $\mathrm{Y}$ & $\mathrm{Y}$ & $\mathrm{Y}$ & $\mathrm{Y}$ & $\mathrm{Y}$ & $\mathrm{Y}$ & $\mathrm{Y}$ \\
\hline Clustered by year & $\mathrm{Y}$ & $\mathrm{Y}$ & $\mathrm{Y}$ & $\mathrm{Y}$ & $\mathrm{Y}$ & $\mathrm{Y}$ & $\mathrm{Y}$ & $\mathrm{Y}$ & $\mathrm{Y}$ & $\mathrm{Y}$ & $\mathrm{Y}$ & $\mathrm{Y}$ \\
\hline $\mathrm{R}^{2}$ & 0.518 & 0.534 & 0.526 & 0.516 & 0.532 & 0.525 & 0.519 & 0.534 & 0.528 & 0.521 & 0.537 & 0.531 \\
\hline $\mathrm{N}$ & 25097 & 25063 & 23634 & 25097 & 25063 & 23634 & 25097 & 25063 & 23634 & 25097 & 25063 & 23634 \\
\hline
\end{tabular}


Panel B: Analysts' Forecast Dispersion

\begin{tabular}{|c|c|c|c|c|c|c|c|c|c|c|c|c|}
\hline & \multicolumn{3}{|c|}{$\begin{array}{c}\text { Accrual-Based } \\
\text { Earnings Management (EM) }\end{array}$} & \multicolumn{3}{|c|}{$\begin{array}{c}\text { Real Activities Manipulation } \\
\text { (RAM) } \\
\end{array}$} & \multicolumn{3}{|c|}{$\begin{array}{c}\text { Financial Statement Comparability } \\
(\text { (FSC) }\end{array}$} & \multicolumn{3}{|c|}{$E M+R A M+F S C$} \\
\hline & (1) & (2) & (3) & (4) & (5) & (6) & (7) & (8) & $(9)$ & $(10)$ & $(11)$ & (12) \\
\hline & FDISPER & FDISPER & FDISPER & FDISPER & FDISPER & FDISPER & FDISPER & FDISPER & FDISPER & FDISPER & FDISPER & FDISPER \\
\hline \multirow[t]{2}{*}{ UNION } & $0.030^{* *}$ & $0.033^{* *}$ & $0.032^{* *}$ & $0.035^{* * *}$ & $0.034 * *$ & $0.032^{* *}$ & $0.035^{* * *}$ & $0.035^{* * *}$ & $0.034 * * *$ & $0.033^{* *}$ & $0.033^{* *}$ & $0.032^{* * *}$ \\
\hline & $(0.020)$ & $(0.019)$ & $(0.016)$ & $(0.007)$ & $(0.016)$ & $(0.012)$ & $(0.006)$ & $(0.010)$ & $(0.006)$ & $(0.012)$ & $(0.016)$ & $(0.009)$ \\
\hline \multirow[t]{2}{*}{$A B S \_D A$} & $0.043^{* * *}$ & $0.044 * * *$ & $0.040 * * *$ & & & & & & & $0.045^{* * *}$ & $0.048^{* * *}$ & $0.044 * * *$ \\
\hline & $(0.002)$ & $(0.001)$ & $(0.002)$ & & & & & & & $(0.001)$ & $(0.001)$ & $(0.001)$ \\
\hline \multirow[t]{2}{*}{ Combined_RAM } & & & & $0.009 * *$ & $0.011 * *$ & $0.011^{* *}$ & & & & $0.011 * * *$ & $0.013^{* *}$ & $0.013^{* *}$ \\
\hline & & & & $(0.016)$ & $(0.030)$ & $(0.026)$ & & & & $(0.005)$ & $(0.013)$ & $(0.013)$ \\
\hline \multirow[t]{2}{*}{ CompAcct4 } & & & & & & & $-0.004 * * *$ & $-0.003^{* * *}$ & $-0.005^{* * *}$ & $-0.004^{* * *}$ & $-0.003 * *$ & $-0.005^{* * *}$ \\
\hline & & & & & & & $(0.006)$ & $(0.010)$ & $(0.006)$ & $(0.010)$ & $(0.013)$ & $(0.008)$ \\
\hline Other controls & $\mathrm{Y}$ & $\mathrm{Y}$ & $\mathrm{Y}$ & $\mathrm{Y}$ & $\mathrm{Y}$ & $\mathrm{Y}$ & $\mathrm{Y}$ & $\mathrm{Y}$ & $\mathrm{Y}$ & $\mathrm{Y}$ & $\mathrm{Y}$ & $\mathrm{Y}$ \\
\hline Firm FE & $\mathrm{Y}$ & $\mathrm{Y}$ & $\mathrm{Y}$ & $\mathrm{Y}$ & $\mathrm{Y}$ & $\mathrm{Y}$ & $\mathrm{Y}$ & $\mathrm{Y}$ & $\mathrm{Y}$ & $\mathrm{Y}$ & $\mathrm{Y}$ & $\mathrm{Y}$ \\
\hline Year FE & $\mathrm{Y}$ & $\mathrm{N}$ & $\mathrm{N}$ & $\mathrm{Y}$ & $\mathrm{N}$ & $\mathrm{N}$ & $\mathrm{Y}$ & $\mathrm{N}$ & $\mathrm{N}$ & $\mathrm{Y}$ & $\mathrm{N}$ & $\mathrm{N}$ \\
\hline Industry $\times$ Year FE & $\mathrm{N}$ & $\mathrm{Y}$ & $\mathrm{Y}$ & $\mathrm{N}$ & $\mathrm{Y}$ & $\mathrm{Y}$ & $\mathrm{N}$ & $\mathrm{Y}$ & $\mathrm{Y}$ & $\mathrm{N}$ & $\mathrm{Y}$ & $\mathrm{Y}$ \\
\hline State FE & $\mathrm{N}$ & $\mathrm{N}$ & $\mathrm{Y}$ & $\mathrm{N}$ & $\mathrm{N}$ & $\mathrm{Y}$ & $\mathrm{N}$ & $\mathrm{N}$ & $\mathrm{Y}$ & $\mathrm{N}$ & $\mathrm{N}$ & $\mathrm{Y}$ \\
\hline Clustered by ind. & $\mathrm{Y}$ & $\mathrm{Y}$ & $\mathrm{Y}$ & $\mathrm{Y}$ & $\mathrm{Y}$ & $\mathrm{Y}$ & $\mathrm{Y}$ & $\mathrm{Y}$ & $\mathrm{Y}$ & $\mathrm{Y}$ & $\mathrm{Y}$ & $\mathrm{Y}$ \\
\hline Clustered by year & $\mathrm{Y}$ & $\mathrm{Y}$ & $\mathrm{Y}$ & $\mathrm{Y}$ & $\mathrm{Y}$ & $\mathrm{Y}$ & $\mathrm{Y}$ & $\mathrm{Y}$ & $\mathrm{Y}$ & $\mathrm{Y}$ & $\mathrm{Y}$ & $\mathrm{Y}$ \\
\hline $\mathrm{R}^{2}$ & 0.604 & 0.618 & 0.605 & 0.603 & 0.617 & 0.604 & 0.603 & 0.617 & 0.605 & 0.605 & 0.619 & 0.606 \\
\hline $\mathrm{N}$ & 25065 & 25031 & 23601 & 25065 & 25031 & 23601 & 25065 & 25031 & 23601 & 25065 & 25031 & 23601 \\
\hline
\end{tabular}




\section{Table 5: Subsample Analysis: RTW States versus Non-RTW States}

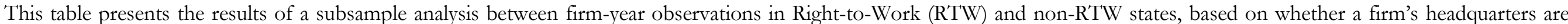

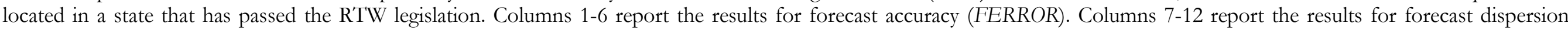

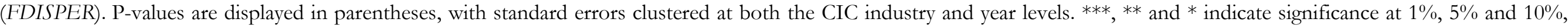
respectively. All variables are defined in the appendix.

Forecast Error (FERROR)

\begin{tabular}{|c|c|c|c|c|c|c|c|c|c|c|c|c|}
\hline & \multicolumn{6}{|c|}{ 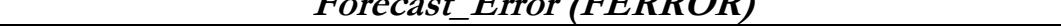 } & \multicolumn{6}{|c|}{ 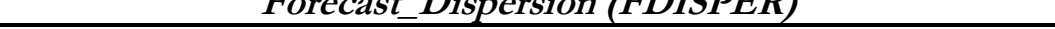 } \\
\hline & \multicolumn{3}{|c|}{ Non-RTW States } & \multicolumn{3}{|c|}{ RTW States } & \multicolumn{3}{|c|}{ Non-RTW States } & \multicolumn{3}{|c|}{ RTW States } \\
\hline & $(1)$ & $(2)$ & (3) & $(4)$ & $(5)$ & $(6)$ & $(7)$ & $(8)$ & $(9)$ & $(10)$ & $(11)$ & $(12)$ \\
\hline \multirow[t]{2}{*}{ UNION } & $0.079 * * *$ & $0.054 * *$ & $0.061 * *$ & 0.027 & -0.048 & -0.048 & $0.044^{* * *}$ & $0.042 * *$ & $0.039 * *$ & 0.005 & 0.000 & 0.000 \\
\hline & $(0.007)$ & $(0.028)$ & $(0.013)$ & $(0.464)$ & $(0.467)$ & $(0.467)$ & $(0.009)$ & $(0.021)$ & $(0.020)$ & $(0.827)$ & $(0.994)$ & $(0.994)$ \\
\hline All controls & $\mathrm{Y}$ & $\mathrm{Y}$ & $\mathrm{Y}$ & $\mathrm{Y}$ & $\mathrm{Y}$ & $\mathrm{Y}$ & $\mathrm{Y}$ & $\mathrm{Y}$ & $\mathrm{Y}$ & $\mathrm{Y}$ & $\mathrm{Y}$ & $\mathrm{Y}$ \\
\hline Firm FE & $\mathrm{Y}$ & $\mathrm{Y}$ & $\mathrm{Y}$ & $\mathrm{Y}$ & $\mathrm{Y}$ & $\mathrm{Y}$ & $\mathrm{Y}$ & $\mathrm{Y}$ & $\mathrm{Y}$ & $\mathrm{Y}$ & $\mathrm{Y}$ & $\mathrm{Y}$ \\
\hline Year FE & $\mathrm{Y}$ & $\mathrm{N}$ & $\mathrm{N}$ & $\mathrm{Y}$ & $\mathrm{N}$ & $\mathrm{N}$ & $\mathrm{Y}$ & $\mathrm{N}$ & $\mathrm{N}$ & $\mathrm{Y}$ & $\mathrm{N}$ & $\mathrm{N}$ \\
\hline Industry $\times$ Year FE & $\mathrm{N}$ & $\mathrm{Y}$ & $\mathrm{Y}$ & $\mathrm{N}$ & $\mathrm{Y}$ & $\mathrm{Y}$ & $\mathrm{N}$ & $\mathrm{Y}$ & $\mathrm{Y}$ & $\mathrm{N}$ & $\mathrm{Y}$ & $\mathrm{Y}$ \\
\hline State FE & $\mathrm{N}$ & $\mathrm{N}$ & $\mathrm{Y}$ & $\mathrm{N}$ & $\mathrm{N}$ & $\mathrm{Y}$ & $\mathrm{N}$ & $\mathrm{N}$ & Y & $\mathrm{N}$ & $\mathrm{N}$ & $\mathrm{Y}$ \\
\hline Clustered by industry & $\mathrm{Y}$ & $\mathrm{Y}$ & $\mathrm{Y}$ & $\mathrm{Y}$ & $\mathrm{Y}$ & $\mathrm{Y}$ & $\mathrm{Y}$ & $\mathrm{Y}$ & $\mathrm{Y}$ & $\mathrm{Y}$ & $\mathrm{Y}$ & $\mathrm{Y}$ \\
\hline Clustered by year & Y & Y & $\mathrm{Y}$ & $\mathrm{Y}$ & $\mathrm{Y}$ & Y & $\mathrm{Y}$ & $\mathrm{Y}$ & $\mathrm{Y}$ & $\mathrm{Y}$ & Y & Y \\
\hline $\mathrm{R}^{2}$ & 0.515 & 0.536 & 0.528 & 0.545 & 0.579 & 0.579 & 0.588 & 0.605 & 0.585 & 0.658 & 0.693 & 0.693 \\
\hline $\mathrm{N}$ & 18396 & 18334 & 16905 & 6679 & 6603 & 6603 & 18369 & 18311 & 16881 & 6674 & 6598 & 6598 \\
\hline
\end{tabular}


Table 6: Subsample Analysis: Low-Skilled Industries versus High-Skilled Industries

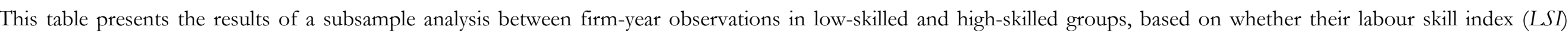

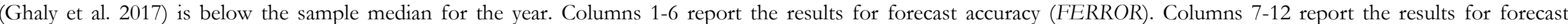

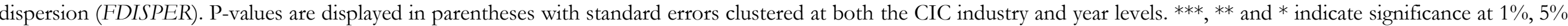
and $10 \%$, respectively. All variables are defined in the appendix.

\section{Forecast_Error (FERROR)}

\begin{tabular}{|c|c|c|c|c|c|c|c|c|c|c|c|c|}
\hline \multirow[b]{3}{*}{ UNION } & \multicolumn{3}{|c|}{ Low-Skilled Industries } & \multicolumn{3}{|c|}{ High-Skilled Industries } & \multicolumn{3}{|c|}{ Low-Skilled Industries } & \multicolumn{3}{|c|}{ High-Skilled Industries } \\
\hline & $(1)$ & (2) & (3) & $(4)$ & $(5)$ & $(6)$ & $(7)$ & $(8)$ & (9) & $(10)$ & $(11)$ & $(12)$ \\
\hline & $0.074 *$ & $0.068^{* *}$ & $0.082^{* *}$ & 0.060 & -0.125 & -0.098 & $0.036^{* *}$ & 0.029 & 0.026 & 0.072 & 0.041 & 0.040 \\
\hline All Controls & $\mathrm{Y}$ & $\mathrm{Y}$ & $\mathrm{Y}$ & $\mathrm{Y}$ & $\mathrm{Y}$ & $\mathrm{Y}$ & $\mathrm{Y}$ & $\mathrm{Y}$ & $\mathrm{Y}$ & $\mathrm{Y}$ & $\mathrm{Y}$ & $\mathrm{Y}$ \\
\hline Firm FE & $\mathrm{Y}$ & $\mathrm{Y}$ & $\mathrm{Y}$ & $\mathrm{Y}$ & $\mathrm{Y}$ & $\mathrm{Y}$ & $\mathrm{Y}$ & $\mathrm{Y}$ & $\mathrm{Y}$ & $\mathrm{Y}$ & $\mathrm{Y}$ & $\mathrm{Y}$ \\
\hline Year FE & $\mathrm{Y}$ & $\mathrm{N}$ & $\mathrm{N}$ & $\mathrm{Y}$ & $\mathrm{N}$ & $\mathrm{N}$ & $\mathrm{Y}$ & $\mathrm{N}$ & $\mathrm{N}$ & $\mathrm{Y}$ & $\mathrm{N}$ & $\mathrm{N}$ \\
\hline Industry $\times$ Year FE & $\mathrm{N}$ & $\mathrm{Y}$ & $\mathrm{Y}$ & $\mathrm{N}$ & $\mathrm{Y}$ & $\mathrm{Y}$ & $\mathrm{N}$ & $\mathrm{Y}$ & $\mathrm{Y}$ & $\mathrm{N}$ & $\mathrm{Y}$ & $\mathrm{Y}$ \\
\hline State FE & $\mathrm{N}$ & $\mathrm{N}$ & $\mathrm{Y}$ & $\mathrm{N}$ & $\mathrm{N}$ & $\mathrm{Y}$ & $\mathrm{N}$ & $\mathrm{N}$ & $\mathrm{Y}$ & $\mathrm{N}$ & $\mathrm{N}$ & $\mathrm{Y}$ \\
\hline Clustered by industry & $\mathrm{Y}$ & $\mathrm{Y}$ & $\mathrm{Y}$ & $\mathrm{Y}$ & $\mathrm{Y}$ & $\mathrm{Y}$ & $\mathrm{Y}$ & $\mathrm{Y}$ & $\mathrm{Y}$ & $\mathrm{Y}$ & $\mathrm{Y}$ & $\mathrm{Y}$ \\
\hline Clustered by year & $\mathrm{Y}$ & $\mathrm{Y}$ & $\mathrm{Y}$ & $\mathrm{Y}$ & $\mathrm{Y}$ & $\mathrm{Y}$ & $\mathrm{Y}$ & $\mathrm{Y}$ & $\mathrm{Y}$ & $\mathrm{Y}$ & $\mathrm{Y}$ & $\mathrm{Y}$ \\
\hline $\mathrm{R}^{2}$ & 0.537 & 0.565 & 0.550 & 0.546 & 0.554 & 0.548 & 0.647 & 0.669 & 0.646 & 0.659 & 0.665 & 0.648 \\
\hline $\mathrm{N}$ & 8378 & 8362 & 7767 & 7624 & 7607 & 6967 & 8368 & 8352 & 7759 & 7615 & 7598 & 6956 \\
\hline
\end{tabular}




\section{Table 7: Subsample Analysis: Labour Costs Channel}

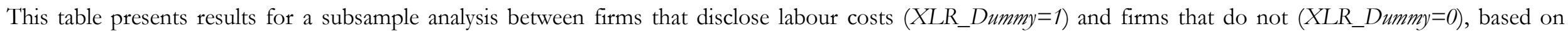
whether labour-related expense (XLR) is reported in the Compustat database. Columns 1-6 report the results for forecast accuracy (FERROR). Columns 7-12 report

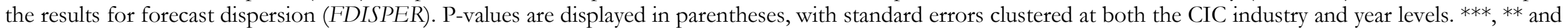
$*$ indicate significance at $1 \%, 5 \%$ and $10 \%$, respectively. All variables are defined in the appendix.

\begin{tabular}{|c|c|c|c|c|c|c|c|c|c|c|c|c|}
\hline & \multicolumn{6}{|c|}{ Forecast_Error (FERROR) } & \multicolumn{6}{|c|}{ Forecast_Dispersion (FDISPER) } \\
\hline & \multicolumn{3}{|c|}{$\left(X L R \_D u m m y=0\right)$} & \multicolumn{3}{|c|}{ XLR_Dummy=1) } & \multicolumn{3}{|c|}{$\left(X L R \_D u m m y=0\right)$} & \multicolumn{3}{|c|}{ XLR_Dummy=1) } \\
\hline \multirow{3}{*}{ UNION } & $(1)$ & $(2)$ & $(3)$ & $(4)$ & $(5)$ & $(6)$ & $(7)$ & $(8)$ & $(9)$ & $(10)$ & $(11)$ & $(12)$ \\
\hline & $0.071 * * *$ & $0.059 * * *$ & $0.064 * * *$ & -0.049 & -0.065 & -0.055 & $0.038^{* * *}$ & $0.044 * * *$ & $0.042^{* * *}$ & -0.029 & -0.069 & -0.051 \\
\hline & $(0.001)$ & $(0.008)$ & $(0.003)$ & $(0.373)$ & $(0.311)$ & $(0.410)$ & -0.005 & -0.003 & -0.002 & -0.211 & -0.237 & -0.416 \\
\hline All controls & $\mathrm{Y}$ & $\mathrm{Y}$ & $\mathrm{Y}$ & $\mathrm{Y}$ & $\mathrm{Y}$ & $\mathrm{Y}$ & $\mathrm{Y}$ & $\mathrm{Y}$ & $\mathrm{Y}$ & $\mathrm{Y}$ & $\mathrm{Y}$ & $\mathrm{Y}$ \\
\hline Firm FE & $\mathrm{Y}$ & $\mathrm{Y}$ & $\mathrm{Y}$ & $\mathrm{Y}$ & $\mathrm{Y}$ & $\mathrm{Y}$ & $\mathrm{Y}$ & $\mathrm{Y}$ & $\mathrm{Y}$ & $\mathrm{Y}$ & $\mathrm{Y}$ & $\mathrm{Y}$ \\
\hline Year FE & $\mathrm{Y}$ & $\mathrm{N}$ & $\mathrm{N}$ & $\mathrm{Y}$ & $\mathrm{N}$ & $\mathrm{N}$ & $\mathrm{Y}$ & $\mathrm{N}$ & $\mathrm{N}$ & $\mathrm{Y}$ & $\mathrm{N}$ & $\mathrm{N}$ \\
\hline Industry $\times$ Year FE & $\mathrm{N}$ & $\mathrm{Y}$ & $\mathrm{Y}$ & $\mathrm{N}$ & $\mathrm{Y}$ & $\mathrm{Y}$ & $\mathrm{N}$ & $\mathrm{Y}$ & $\mathrm{Y}$ & $\mathrm{N}$ & $\mathrm{Y}$ & $\mathrm{Y}$ \\
\hline State FE & $\mathrm{N}$ & $\mathrm{N}$ & $\mathrm{Y}$ & $\mathrm{N}$ & $\mathrm{N}$ & $\mathrm{Y}$ & $\mathrm{N}$ & $\mathrm{N}$ & $\mathrm{Y}$ & $\mathrm{N}$ & $\mathrm{N}$ & $\mathrm{Y}$ \\
\hline Clustered by industry & $\mathrm{Y}$ & $\mathrm{Y}$ & $\mathrm{Y}$ & $\mathrm{Y}$ & $\mathrm{Y}$ & $\mathrm{Y}$ & $\mathrm{Y}$ & $\mathrm{Y}$ & $\mathrm{Y}$ & $\mathrm{Y}$ & $\mathrm{Y}$ & $\mathrm{Y}$ \\
\hline Clustered by year & $\mathrm{Y}$ & $\mathrm{Y}$ & $\mathrm{Y}$ & $\mathrm{Y}$ & $\mathrm{Y}$ & $\mathrm{Y}$ & $\mathrm{Y}$ & $\mathrm{Y}$ & $\mathrm{Y}$ & $\mathrm{Y}$ & $\mathrm{Y}$ & $\mathrm{Y}$ \\
\hline $\mathrm{R}^{2}$ & 0.523 & 0.538 & 0.535 & 0.611 & 0.630 & 0.630 & 0.600 & 0.614 & 0.608 & 0.741 & 0.727 & 0.727 \\
\hline $\mathrm{N}$ & 23333 & 23293 & 22280 & 1719 & 1558 & 1134 & 23304 & 23264 & 22252 & 1717 & 1556 & 1130 \\
\hline
\end{tabular}




\section{Table 8. Labour Unions and Analyst Optimism}

This table presents results for the relation between the labour unionisation rate and analysts' propensity for issuing optimistic earnings forecasts, based on a probit model. The dependent variable is Optimism_Bias, which takes the value of one if the estimated EPS issued by the analysts is larger than the actual EPS, and zero otherwise. The variable of interest is UNION in Columns 1-2. For robustness, in Columns 3-4, we use a dummy variable, High_UNION, which is equal to one if the labour unionisation rate is above the sample median, and zero otherwise. All regression models include industry-year fixed effects. P-values are displayed in parentheses, with standard errors clustered at the CIC industry level. ${ }^{* *}, * *$ and $*$ indicate significance at $1 \%, 5 \%$ and $10 \%$, respectively. All variables are defined in the appendix.

\begin{tabular}{|c|c|c|c|c|}
\hline & Optimism_Bias & Optimism_Bias & Optimism_Bias & Optimism_Bias \\
\hline & (1) & (2) & (3) & (4) \\
\hline UNION & $\begin{array}{c}0.636^{* * *} \\
(0.003)\end{array}$ & $\begin{array}{c}0.448^{* *} \\
(0.017)\end{array}$ & & \\
\hline High_UNION & & & $\begin{array}{c}0.095^{* * *} \\
(0.009)\end{array}$ & $\begin{array}{c}0.078^{* *} \\
(0.014)\end{array}$ \\
\hline SIZE & & $\begin{array}{c}-0.182^{* * *} \\
(0.000)\end{array}$ & & $\begin{array}{c}-0.182 * * * \\
(0.000)\end{array}$ \\
\hline MTB & & $\begin{array}{l}-0.000 \\
(0.855)\end{array}$ & & $\begin{array}{l}-0.000 \\
(0.836)\end{array}$ \\
\hline LOSS & & $\begin{array}{c}0.727 * * * \\
(0.000)\end{array}$ & & $\begin{array}{c}0.727 * * * \\
(0.000)\end{array}$ \\
\hline EARNSURP & & $\begin{array}{c}-0.000^{* *} \\
(0.037)\end{array}$ & & $\begin{array}{c}-0.000^{* *} \\
(0.038)\end{array}$ \\
\hline LEV & & $\begin{array}{c}0.310^{* * *} \\
(0.000)\end{array}$ & & $\begin{array}{c}0.313 * * * \\
(0.000)\end{array}$ \\
\hline$R D \_E X P$ & & $\begin{array}{c}0.060 \\
(0.772)\end{array}$ & & $\begin{array}{c}0.073 \\
(0.722)\end{array}$ \\
\hline$A G E$ & & $\begin{array}{c}0.057 * * * \\
(0.005)\end{array}$ & & $\begin{array}{c}0.057 * * * \\
(0.005)\end{array}$ \\
\hline ZSCORE & & $\begin{array}{l}-0.003 \\
(0.183)\end{array}$ & & $\begin{array}{l}-0.003 \\
(0.189)\end{array}$ \\
\hline SD_INCOME & & $\begin{array}{c}-0.307 * * * \\
(0.004)\end{array}$ & & $\begin{array}{c}-0.305^{* * *} \\
(0.004)\end{array}$ \\
\hline$S D \_S T K$ & & $\begin{array}{c}-3.223^{* *} \\
(0.018)\end{array}$ & & $\begin{array}{c}-3.263 * * \\
(0.017)\end{array}$ \\
\hline ANALYST_NUM & & $\begin{array}{c}0.005^{* * *} \\
(0.000)\end{array}$ & & $\begin{array}{c}0.005^{* * *} \\
(0.000)\end{array}$ \\
\hline$A B S \_D A$ & & $\begin{array}{c}-0.379 * * * \\
(0.008)\end{array}$ & & $\begin{array}{c}-0.372 * * * \\
(0.010)\end{array}$ \\
\hline Combined_RAM & & $\begin{array}{c}0.189 * * * \\
(0.000)\end{array}$ & & $\begin{array}{c}0.189 * * * \\
(0.000)\end{array}$ \\
\hline CompAcct4 & & $\begin{array}{l}-0.017 \\
(0.216) \\
\end{array}$ & & $\begin{array}{l}-0.017 \\
(0.211)\end{array}$ \\
\hline Industry $\times$ Year FE & $\mathrm{Y}$ & $\mathrm{Y}$ & $\mathrm{Y}$ & $\mathrm{Y}$ \\
\hline Pseudo-R ${ }^{2}$ & 0.070 & 0.139 & 0.070 & 0.139 \\
\hline $\mathrm{N}$ & 27016 & 25669 & 27016 & 25669 \\
\hline
\end{tabular}




\section{Appendix: Definition of Variables}

\begin{tabular}{|c|c|}
\hline Variable & Definition \\
\hline UNION & $\begin{array}{l}\text { Industry-level unionisation rate, defined as the percentage of employees represented by } \\
\text { labour unions in a specific industry. }\end{array}$ \\
\hline ANALYST_NUM & Number of financial analysts following the firm \\
\hline FERROR & $\begin{array}{l}\text { Forecast error, defined as the average absolute value of the difference between } \\
\text { estimated and actual EPS for all the earnings forecasts made for the firm within the } 12 \\
\text { months of the earnings announcement, scaled by the share price at year } t\end{array}$ \\
\hline FDISPER & $\begin{array}{l}\text { Forecast dispersion, defined as the standard deviation of all the earnings forecasts made } \\
\text { for the firm within the } 12 \text { months of the earnings announcement, scaled by the share } \\
\text { price at year } \mathrm{t}\end{array}$ \\
\hline SIZE & The logarithm of a firm's market value of equity \\
\hline MTB & The market value of equity divided by the book value of equity \\
\hline LOSS & $\begin{array}{l}\text { An indicator variable equal to one for negative actual earnings per share before } \\
\text { extraordinary items and zero otherwise }\end{array}$ \\
\hline EARNSURP & $\begin{array}{l}\text { Earnings surprises, defined as the absolute difference between income before } \\
\text { extraordinary items at time } \mathrm{t} \text { and income before extraordinary items at time } \mathrm{t}-1 \text {, divided } \\
\text { by income before extraordinary items at time } \mathrm{t}-1\end{array}$ \\
\hline LEV & Total debt divided by total assets \\
\hline RD_EXP & Research and development expense divided by total assets \\
\hline AGE & $\begin{array}{l}\text { Firm age, measured as the logarithm of the difference between the current year and the } \\
\text { year when the firm appeared in CRSP for the first time }\end{array}$ \\
\hline ZSCORE & $\begin{array}{l}\text { Altman Z Score }=1.2(\text { working capital } / \text { total assets })+1.4 \text { (retained earnings } / \text { total assets }) \\
+3.3(\text { EBIT } / \text { total assets })+0.6 \text { (market value of equity/book value of total liabilities })+ \\
\text { (sales/total assets) }\end{array}$ \\
\hline SD_INCOME & Standard deviation of return on assets over the past five years \\
\hline SD_STK & Standard deviation of return over a 365 -day period prior to the fiscal year-end \\
\hline$A B S \_D A$ & $\begin{array}{l}\text { Absolute value of performance-matched discretionary accruals, computed using the } \\
\text { Modified Jones Model (Kothari et al. 2005) }\end{array}$ \\
\hline Combined_RAM & $\begin{array}{l}\text { The sum of the standardized three real earnings management proxies, i.e., abnormal } \\
\text { levels of cash flow from operations }\left(R \_C F O\right) \text {, discretionary expenses }\left(R \_D I S X\right) \text { and } \\
\text { production costs }\left(R \_P R O D\right) \text { (Cohen et al. 2008) }\end{array}$ \\
\hline CompAcct4 & $\begin{array}{l}\text { Firm-specific financial statement comparability score, measured as the average score of } \\
\text { the four peer firms with the highest comparability scores (De Franco et al. 2011) }\end{array}$ \\
\hline$R T W$ & $\begin{array}{l}\text { Dummy variable equal to one if the firm is headquartered in a state that has passed } \\
\text { Right-to-Work legislation }\end{array}$ \\
\hline LowSkill & $\begin{array}{l}\text { Dummy variable equal to one if the industry-level labour skills index developed by } \\
\text { Ghaly et al. (2017) is below the sample median for the year, and zero otherwise }\end{array}$ \\
\hline XLR_Dummy & $\begin{array}{l}\text { Dummy variable equal to one if the labour-related expense variable (XLR) is available, } \\
\text { and zero otherwise }\end{array}$ \\
\hline Optimism_Bias & $\begin{array}{l}\text { Dummy variable equal to one if the average estimated EPS is larger than the actual EPS } \\
\text { for all the earnings forecasts made for the firm within the } 12 \text { months of the earnings } \\
\text { announcement, and zero otherwise }\end{array}$ \\
\hline High_UNION & $\begin{array}{l}\text { Dummy variable equal to one if the industry's labour unionisation rate is above the } \\
\text { sample median, and zero otherwise }\end{array}$ \\
\hline
\end{tabular}

